\title{
Aneuploidogenic effects and DNA oxidation induced in vitro by differently sized gold nanoparticles
}

This article was published in the following Dove Press journal:

International Journal of Nanomedicine

8 May 2014

Number of times this article has been viewed

\section{Sebastiano Di Bucchianico \\ Maria Rita Fabbrizi' \\ Silvia Cirillo' \\ Chiara Uboldi' \\ Douglas Gilliland ${ }^{2}$ \\ Eugenia Valsami-Jones ${ }^{3,4}$ \\ Lucia Migliore'}

'Department of Translational Research and New Technologies in Medicine and Surgery, Medical Genetics Unit, University of Pisa, Pisa, Italy; ${ }^{2}$ European CommissionJoint Research Centre, Institute for Health and Consumer Protection, NanoBioSciences Unit, Ispra, Italy; ${ }^{3}$ School of Geography, Earth and Environmental Sciences, University of Birmingham, Edgbaston, Birmingham, UK; ${ }^{4}$ Earth Sciences, Natural History Museum, Cromwell Road, London, UK

Correspondence: Sebastiano D Bucchianico

University of Pisa,Via San Giuseppe,

22 - $56 \mid 26$ Pisa, Italy

Tel $+39050221 \quad 1028$

Fax +39050 22I 1034

Email sebastiano.dibucchianico@for. unipi.it

\begin{abstract}
Gold nanoparticles (Au NPs) are used in many fields, including biomedical applications; however, no conclusive information on their potential cytotoxicity and genotoxicity mechanisms is available. For this reason, experiments in human primary lymphocytes and murine macrophages (Raw264.7) were performed exposing cells to spherical citrate-capped $\mathrm{Au}$ NPs with two different nominal diameters $(5 \mathrm{~nm}$ and $15 \mathrm{~nm}$ ). The proliferative activity, mitotic, apoptotic, and necrotic markers, as well as chromosomal damage were assessed by the cytokinesis-block micronucleus cytome assay. Fluorescence in situ hybridization with human and murine pancentromeric probes was applied to distinguish between clastogenic and aneuploidogenic effects. Our results indicate that $5 \mathrm{~nm}$ and $15 \mathrm{~nm}$ Au NPs are able to inhibit cell proliferation by apoptosis and to induce chromosomal damage, in particular chromosome mis-segregation. DNA strand breaks were detected by comet assay, and the modified protocol using endonuclease-III and formamidopyrimidine-DNA glycosylase restriction enzymes showed that pyrimidines and purines were oxidatively damaged by Au NPs. Moreover, we show a sizeindependent correlation between the cytotoxicity of Au NPs and their tested mass concentration or absolute number, and genotoxic effects which were more severe for Au NP $15 \mathrm{~nm}$ compared to $\mathrm{Au}$ NP $5 \mathrm{~nm}$. Results indicate that apoptosis, aneuploidy, and DNA oxidation play a pivotal role in the cytotoxicity and genotoxicity exerted by Au NPs in our cell models.
\end{abstract}

Keywords: Au nanoparticles, cytotoxicity, aneuploidy, oxidative DNA damage, micronuclei, particle size

\section{Introduction}

Evidence has emerged for the important role of physicochemical properties in controlling the cellular uptake and toxicity of nanoparticles in a biological system. In vitro uptake of gold nanoparticles (Au NPs) depends on the particle physical dimensions, suggesting that size and shape can mediate particle-cell interactions, receptor recycling rates and exocytosis. ${ }^{1} \mathrm{Au}$ NPs enter the cells via a clathrin-mediated endocytosis and are exocytosed by a size-dependent relationship. ${ }^{2}$ It is also known that $10-100 \mathrm{~nm}$ gold particles can enter or exit cells via wrapping, even in the absence of clathrin- or caveolin-coated vesicles. ${ }^{3}$ However, the toxicity of Au NPs, as well as of others such as silver NPs, might not correlate with the level of uptake but cell-type and the size can play a role. ${ }^{4,5}$ In fact, $20 \mathrm{~nm}$ citrated Au NPs resulted as more toxic than $14 \mathrm{~nm}$ ones in ovarian hamster's cells but not in bronchial and kidney derived cell cultures. ${ }^{4}$ However, even if it is recognized that the cell type plays a role in the uptake of Au NPs, the size is not involved: differently sized Au NPs displayed a similar uptake in epithelial (A549 and NCIH441) and in endothelial (HDMEC and hCMEC) cells, but endothelial cells were shown to internalize a higher amount of Au NPs than epithelial ones. ${ }^{6,7}$ Despite these 
indications, it remains unclear how the physicochemical properties of NPs change when the exposure occurs in a biological system. In fact, it is known that different serum proteins form protein coronas, which significantly modulate NPs behavior. ${ }^{8}$ The cellular environment contains a variety of proteins rapidly adsorbing onto the surface of NPs and forming a protein corona which defines the NPs biological identity, altering size, aggregation state, surface chemistry, uptake and ion release. ${ }^{9}$ The alteration of these physicochemical properties can result in increasing or protecting from NPs toxicity. Since Au NPs are used in medical applications, such as photothermal therapy, ${ }^{10}$ and are often administered intravenously, the adsorption of blood proteins onto their surface is one of the most relevant and studied parameters. Blood is a complex human-derived proteome and contains other tissue subsets of proteins, ${ }^{11}$ which potentially interact with NPs changing their physicochemical characteristics and their biological identity. For example, NPs size and surface chemistry can mediate plasma and serum protein adsorption to $\mathrm{Au}$ NPs and their biological responses and/or uptake by macrophages. ${ }^{12,13}$ From the different proteins accumulation patterns, observed as a result of differently sized and surfacecharged Au NPs administered intravenously to rats, Hirn et al concluded that the alterations of the Au NPs surface area, determined by the size of the particles, are the main mechanism determining Au NPs accumulation in various organs and tissues. ${ }^{14}$ Size-dependent tissue distribution of Au NPs was observed upon intravenous administration in mice and sizedependent alterations occurred in vivo in the hepatic tissue of exposed rats. ${ }^{15,16}$ In contrast, monodispersed Au NPs did not exert a higher acute effect compared to their agglomerates, when using pulmonary inflammation as a marker for toxicity after intratracheal instillation in rats. ${ }^{17}$ Furthermore, the model organism Drosophila melanogaster showed DNA fragmentation and significant concentration-dependent and size-independent modulation of expression levels of the genes involved in stress stimuli ( $h s p 70$ and $h s p 83$ ), DNA damage (p53) and apoptosis pathway (Dark, Dronc, and Dredd) upon ingestion of $\mathrm{Au}$ NPs. ${ }^{18}$

To study the toxic mechanisms of Au NPs, we assessed the cytotoxic and genotoxic responses induced by Au NPs in human peripheral blood lymphocytes (PBL) and murine macrophages Raw264.7, by differentiating clastogenic and aneuploidogenic effects, DNA strand breaks and oxidative DNA damage. Cell viability was determined by methylthiazol tetrazolium (MTT) assay, and the proliferative activity, cytotoxicity, mitotic, apoptotic and necrotic markers, as well as the chromosomal damage induced by Au NPs, were assessed by the cytokinesis-block micronucleus cytome assay. To distinguish between clastogenic and aneuploidogenic effects, we performed the fluorescence in situ hybridization (FISH) with human and murine pancentromeric probes. Single cell DNA strand breaks were detected by comet assay, and the oxidative DNA damage induced by $\mathrm{Au}$ NPs was investigated applying the modified comet protocol with endonuclease-III (EndoIII) and formamidopyrimidineDNA glycosylase (Fpg) enzymes. In addition, the data were further analyzed taking into account the mass concentrations and the theoretically calculated number of Au NPs used. To verify whether size is the factor that regulates the toxic responses of Au NPs, we also exposed Raw264.7 cells to Au NPs with different nominal diameters (5 nm and $15 \mathrm{~nm}$ ) at increasing exposure times and increasing absolute numbers of Au NPs.

\section{Material and methods}

\section{Au NPs synthesis and characterization}

$\mathrm{Au}$ NPs of two different sizes (5 nm and $15 \mathrm{~nm}$ ) were prepared and characterized at the Joint Research Centre of the European Commission (Ispra, Italy) as a suspension of $98.5 \mathrm{mg} / \mathrm{L}$ (total Au content) in citrate buffer, as previously reported. ${ }^{19,20}$ Particles were characterized by three different techniques, dynamic light scattering, centrifugal particle sedimentation (CPS), and scanning transmission electron microscopy (STEM), and the zeta potential was determined by Zetasizer ZS-Nano (Malvern Instruments, Worcestershire, UK). To assess if NPs aggregate, their size distribution in the as-synthesized state and following dispersion in complete culture medium $(9.85 \mu \mathrm{g} / \mathrm{mL})$ was measured using the DC24000UHR centrifuge (CPS Instruments, Oosterhout, the Netherlands). The size and shape of the Au NPs was also evaluated using STEM images obtained using a FEI Nova nanolab microscope (FEI, Eindhoven, the Netherlands). The inductively coupled plasma-mass spectrometry technique (ICP-MS, 7700 series, Agilent Technologies Inc., Santa Clara, CA, USA) was used to assess the presence of dissolved ions in the Au NPs suspensions after removal of all solid particulate material by ultrafiltration ( $10 \mathrm{kDa}$ Amicon filters, 20 minutes, room temperature, $1,500 \times g)$.

\section{Cell culture}

We drew 4-6 mL of blood from two healthy volunteers by venipuncture in Li-heparin vials, according to standard procedure. The donors were chosen according to the following criteria: young age, nonsmokers, without pharmacological treatments for at least 3 weeks before donation and without 
any radiological examination performed within the previous 3 months. The PBL were cultured as previously described. ${ }^{21}$

Raw264.7 cells were purchased from the Istituto Zooprofilattico of Brescia (Italy). The cells were cultured in MEM (minimal essential medium) (CELBIO, Milan, Italy) supplemented with 10\% fetal bovine serum (CELBIO), 1\% penicillin/streptomycin (CELBIO), and 1\% L-glutamine (CELBIO). The cell cultures were maintained in a humidified atmosphere $\left(5 \% \mathrm{CO}_{2}\right)$ at $37^{\circ} \mathrm{C}$.

\section{Au NP exposure}

After 24 hours of seeding, the cell cultures were treated either with different mass concentrations $(0.1,1,10$, and $100 \mu \mathrm{g} / \mathrm{mL})$ or with increasing absolute numbers $\left(1 \times 10^{9}\right.$, $1 \times 10^{10}, 1 \times 10^{11}$ ) of $5 \mathrm{~nm}$ and $15 \mathrm{~nm} \mathrm{Au} \mathrm{NPs}$. The tested samples were prepared by diluting suitable aliquots of $\mathrm{Au}$ NPs stock solutions in complete culture medium. The number of Au NPs within each mass concentration dose and the tested number of Au NPs were determined by the following formula:

$$
N=\frac{V_{N P}}{v_{N P}}=\frac{6 \cdot M \cdot m \cdot V_{\text {sample }}}{\rho \cdot \pi \cdot d^{3}}=\frac{6 \cdot V_{\text {sample }}}{\rho \cdot \pi} \cdot \frac{M \cdot m}{d^{3}}
$$

where, $v_{N P}=$ volume of a nanoparticle $=4 / 3 \cdot r^{3} \cdot \pi=1 / 6 \cdot d^{3} \cdot \pi$ ( $r=$ nanoparticle radius; $d=$ nanoparticle diameter), $V_{N P}=$ total volume of nanoparticles in the sample $=\left(M_{N P} / \rho\right)=\left(M \cdot m \cdot V_{\text {sample }}\right) / \rho$ and $M_{N P}=$ mass of nanoparticles in the sample volume $=V_{\text {sample }} \cdot M \cdot \mathrm{m}(\rho=$ specific mass or density expressed as $\mathrm{g} / \mathrm{cm}^{3} ; m=$ molar mass expressed as $\mathrm{g} / \mathrm{mol} ; M=$ molarity; $V_{\text {sample }}=$ sample volume). For Au NPs nanoparticles: $m=197 \mathrm{~g} / \mathrm{mol}$ and $\rho=19.3 \mathrm{~g} / \mathrm{cm}^{3}$.

\section{Cell viability}

Cytotoxicity was assessed by MTT assay. Subconfluent Raw264.7 cells were grown in 96-well plates and exposed to Au NPs suspensions for 2 hours and 24 hours. PBL were treated at the same conditions of adherent Raw264.7 cells. PBL were collected in sterile tubes and resuspended in $0.5 \mathrm{~mL}$ complete MEM; erythrocyte lysis buffer (155 $\mathrm{mM} \mathrm{NH}_{4} \mathrm{Cl}$, $10 \mathrm{mM} \mathrm{KHCO}_{3}, 1 \mathrm{mM} \mathrm{Na}_{2}$ EDTA, $\mathrm{pH} 7.4 ; 3.5 \mathrm{~mL} /$ tube) was added, and after 90 seconds cells were collected by centrifuging (3,000 rpm, 5 minutes). PBL were washed in $3.5 \mathrm{~mL}$ of complete medium and then pelleted (3,000 rpm, 5 minutes). The pellet was resuspended in $3.5 \mathrm{~mL}$ complete MEM and $100 \mu \mathrm{L}$ of the cell suspension was pipetted in each well of a 96-well plate. Hydrogen peroxide $\left(10 \mu \mathrm{M} \mathrm{H}_{2} \mathrm{O}_{2}\right)$ was used as positive control.
After 2 hours and 24 hours of exposure of Raw264.7 and PBL to Au NPs, $10 \mu \mathrm{L}$ of a $5 \mathrm{mg} / \mathrm{mL}$ MTT solution was added to each well (nine wells for each condition). After 3 hours at $37^{\circ} \mathrm{C}$, Raw 264.7 medium was replaced by $100 \mu \mathrm{L}$ of dimethyl sulfoxide (DMSO) and mixed thoroughly to dissolve the formazan crystals; to PBL in suspension, $100 \mu \mathrm{L}$ of DMSO was added without discarding the medium. To limit potential interactions due to the presence of residual NPs that could interfere with the assay, blanks without cells were used to detect the absorption of Au NPs themselves. Absorbance was measured at $570 \mathrm{~nm}$ (630 nm background) and cell viability was determined as the percentage of the blanks subtracted to the corresponding percentage of the exposed cells.

\section{Cytokinesis-block micronucleus cytome assay}

The cytokinesis-block micronucleus cytome (CBMN Cyt) assay after whole blood treatments was performed according to the procedure described by Migliore et al, ${ }^{21}$ while the CBMN Cyt assay on Raw264.7 was performed according to Migliore et al. ${ }^{22}$ The exposure to Au NPs lasted for 48 hours. Mitomycin C $(0.1 \mu \mathrm{g} / \mathrm{mL}$; MMC, Kyowa Hakko Kogyo Co, Chiyoda, Tokyo, Japan) was used as positive control. As described by Fenech, 500 cells were scored to evaluate the percentage of mono-, bi- and multinucleated cells, and the cytokinesis block proliferation index (CBPI) was calculated as an index of cytotoxicity by comparing the distribution of mono-, bi-, and multinucleated cells in the treated and control cells. ${ }^{23}$ The CBPI indicates the average number of cell cycles per cell during the period of exposure to cytoB, and is used to calculate cell proliferation. The number of apoptotic, necrotic, and mitotic cells per 500 cells was also evaluated. The genotoxic potential of Au NPs was evaluated by scoring the binucleated/micronucleated cells frequency as number of 1,000 binucleated cells containing one or more micronuclei $(\mathrm{MN})$. Finally, on these 1,000 binucleated cells other parameters such as nucleoplasmic bridges (NPB), a biomarker of DNA misrepair and/or telomere end-fusions, and nuclear buds (NBUD), a biomarker of elimination of amplified DNA and/or DNA repair complexes, were also scored.

For PBL, data were reported as mean of four independent experiments (from two donors) \pm standard error of the mean (SEM); for Raw264.7 cells, results were plotted as mean of three independent experiments (two replicates each) \pm SEM.

\section{FISH}

Cells to perform FISH were prepared and spotted onto CBMN Cyt slides as previously described. ${ }^{24}$ Samples 
exposed for 48 hours to $0.1 \mu \mathrm{g} / \mathrm{mL}, 1 \mu \mathrm{g} / \mathrm{mL}$, and $10 \mu \mathrm{g} / \mathrm{mL}$ of $\mathrm{Au}$ NPs, and to positive $(0.1 \mu \mathrm{g} / \mathrm{mL} \mathrm{MMC}$, clastogen $)$ and negative controls, were classified as centromere positive or centromere negative based on the presence or on the absence of centromeres in MN. Data were reported as mean of four independent experiments (from two donors) 土 SEM; for Raw264.7 cells, results were plotted as mean of three independent experiments (two replicates each) \pm SEM.

\section{Comet assay and oxidative DNA damage}

DNA damage was measured using the alkaline comet assay as described by Di Bucchianico et al. ${ }^{24}$ The percentage of total DNA fluorescence in tail in a total of 100 randomly selected cells per sample (two replicates, each with 50 cells/slide) was used as a measure of the amount of primary DNA damage. Ten micromolar $\mathrm{H}_{2} \mathrm{O}_{2}$ was used as positive control. Three independent experiments were performed for both 2- and 24-hour treatments. Analysis was carried out by using a Comet Image Analysis System, version 5.5 (Kinetic Imaging, Nottingham, UK).

To determine the presence of oxidized pyrimidine and purine bases, EndoIII and Fpg were used as previously described. ${ }^{24}$ Three independent experiments were performed for both 2- and 24-hour treatments. To determine the number of enzyme-sensitive sites, the difference between the value of the percent DNA fluorescence in tail obtained after digestion with each enzyme and with the buffer only was calculated.

\section{Results}

\section{Characterization of Au NPs}

The characterization of Au NPs was previously reported by Coradeghini et al and is summarized in Table $1 .{ }^{20} \mathrm{UV}$-vis spectrophotometry of Au NPs showed different absorption peaks at $508 \mathrm{~nm}$ and $520 \mathrm{~nm}$ wavelengths, consistent with their different diameters. A good agreement was found between the results of electron microscopy and CPS measurements. The CPS analysis was also used to measure the size distribution of $5 \mathrm{~nm}$ and $15 \mathrm{~nm} \mathrm{Au} \mathrm{NPs} \mathrm{in} \mathrm{culture}$ medium. Results showed that $>70 \%$ of the $5 \mathrm{~nm}$ and $15 \mathrm{~nm}$ $\mathrm{Au}$ NPs are monodispersed, even after being resuspended in complete MEM for 72 hours at $37^{\circ} \mathrm{C}$. The concentration of ions released from the Au NPs suspension, measured by ICP-MS up to 72 hours in complete medium, was for both sizes of $\mathrm{Au}$ NPs below the limit of detection of the instrument $(<1 \mathrm{ppb})$.

\section{Cell viability}

Cell viability was evaluated in PBL and Raw264.7 by MTT assay, a standard in vitro test already optimized to study NP toxicity. ${ }^{25}$ In PBL, $100 \mu \mathrm{g} / \mathrm{mL}$ of $5 \mathrm{~nm}$ Au NPs showed more severe cytotoxicity after 2 hours of exposure (Figure 1), while $15 \mathrm{~nm}$ Au NPs exerted no signs of cytotoxicity. The 24-hour treatments showed a significant decrease in cell viability for both NPs, and in the presence of $15 \mathrm{~nm} \mathrm{Au} \mathrm{NPs} \mathrm{the} \mathrm{effect}$ was dose dependent.

In Raw264.7 cells (Figure 1), the cell viability decreased in a dose-dependent manner after 2 hours of exposure to $5 \mathrm{~nm} \mathrm{Au} \mathrm{NPs}$, and the same was observed after 24 hours of exposure to both $5 \mathrm{~nm}$ and $15 \mathrm{~nm}$ Au NPs. Interestingly, at 2 hours of exposure, the smallest NPs showed higher cytotoxicity in both macrophages and lymphocytes.

\section{Cytotoxicity and cytostasis}

PBL proliferation, measured as CBPI, decreased in a dosedependent manner following exposure to Au NPs (Table 2); $5 \mathrm{~nm} \mathrm{Au} \mathrm{NPs} \mathrm{showed} \mathrm{a} \mathrm{more} \mathrm{effective} \mathrm{antiproliferative}$ activity than $15 \mathrm{~nm} \mathrm{Au} \mathrm{NPs,} \mathrm{which} \mathrm{in} \mathrm{contrast} \mathrm{was} \mathrm{the}$ most effective at the highest tested dose $(100 \mu \mathrm{g} / \mathrm{mL})$. In PBL, significant antimitotic and apoptotic activities were observed after exposure to both Au NPs, but the most severe apoptotic effect was seen after exposure to $10 \mu \mathrm{g} / \mathrm{mL}$ and $100 \mu \mathrm{g} / \mathrm{mL} 15 \mathrm{~nm}$ Au NPs. The necrotic index increased for both Au NPs in a dose-dependent manner; the exposure to $5 \mathrm{~nm}$ Au NPs showed higher necrotic effect than

Table I Au NP characterization

\begin{tabular}{|c|c|c|c|c|c|c|c|c|c|c|}
\hline \multirow{2}{*}{$\begin{array}{l}\text { Au NP } \\
\text { nominal size }\end{array}$} & \multirow{2}{*}{$\begin{array}{l}\text { STEM } \\
\text { Mean } \pm \text { SD } \\
(\mathrm{nm})\end{array}$} & \multicolumn{3}{|c|}{ DLS in native solution } & \multicolumn{3}{|c|}{ CPS in native solution } & \multicolumn{3}{|c|}{ CPS in MEM } \\
\hline & & $\begin{array}{l}\text { Mean } \pm \text { SD } \\
(\mathrm{nm})\end{array}$ & PDI & $\begin{array}{l}\text { Z-pot } \\
(\mathrm{mV})\end{array}$ & $\begin{array}{l}\text { Mean } \\
(\mathrm{nm})\end{array}$ & $\begin{array}{l}\text { Half-width } \\
(\mathrm{nm})\end{array}$ & PDI & $\begin{array}{l}\text { Mean } \\
(\mathrm{nm})\end{array}$ & $\begin{array}{l}\text { Half-width } \\
(\mathrm{nm})\end{array}$ & PDI \\
\hline $5 \mathrm{~nm}$ & $3.3 \pm 1.7$ & $7.1 \pm 2.1$ & 0.097 & $-26 \pm 11$ & 6.6 & 2.2 & 1.37 & 3.4 & 1.5 & 5 \\
\hline $15 \mathrm{~nm}$ & $12.0 \pm 1.0$ & $17.0 \pm 4.7$ & 0.028 & $-30 \pm 12$ & 12.9 & 1.7 & 1.04 & 7.4 & 1.3 & 2.3 \\
\hline
\end{tabular}

Notes: Mean size distribution \pm SD of $5 \mathrm{~nm}$ and $15 \mathrm{~nm}$ Au NPs measured in native solution by STEM, DLS, and CPS. PDI and Z-potential values are also included. Values are expressed as mean of three measurements for DLS and CPS, and for STEM analysis of at least 300 NPs. The mean size distribution of $5 \mathrm{~nm}$ and I5 nm Au NPs obtained by CPS was measured in MEM after 72 hours of incubation at $37^{\circ} \mathrm{C}$. Z-potential measurements of the as-synthesized Au NPs were performed at the physiological $\mathrm{pH}$ range of 6.5-7.5.

Abbreviations: Au NP, gold nanoparticle; CPS, centrifugal particle sedimentation; DLS, dynamic light scattering; MEM, minimal essential medium; PDI, polydispersity index; SD, standard deviation; STEM, scanning transmission electron microscopy; Z-pot, Z-potential. 
MTT 2 h

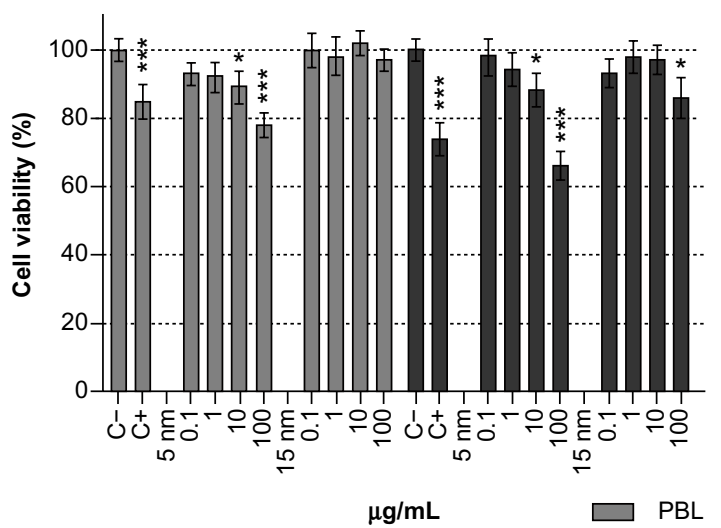

MTT 2 h

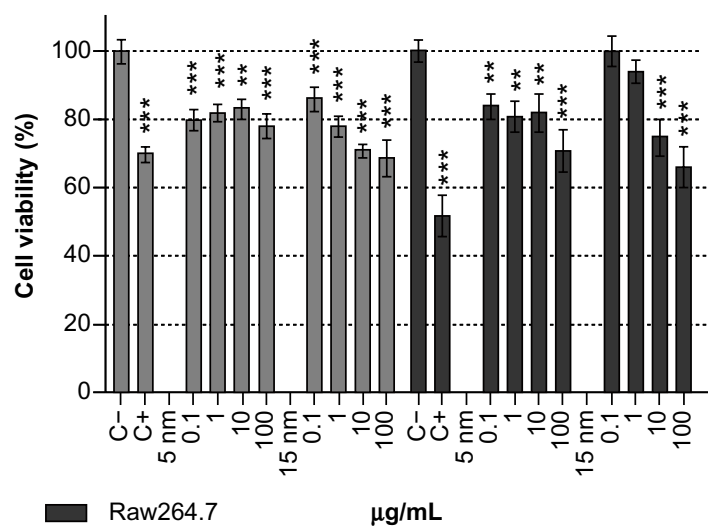

Figure I Cell viability, evaluated by MTT assay, in PBL and Raw264.7 after 2 hours and 24 hours of exposure to $5 \mathrm{~nm}$ and I5 nm Au NPs.

Notes: PBL following 24 hours treatment with Au NP I 5 nm showed a dose-effect relationship ( $P=0.01$ ). Raw 264.7 following 2 hours treatment with $5 \mathrm{~nm}$ Au NPs showed a dose-effect relationship $(P=0.04)$ as well as after 24 hours treatment to $5 \mathrm{~nm}$ and $15 \mathrm{~nm}$ Au NPs $(P=0.03$ and $P=0.016$, respectively). Data show the percent of viable cells normalized to untreated control $( \pm S E M, n=9)$. Statistically significant differences from the $C$ - were determined by Student's $t$-test $(* P<0.05 ; * * P<0.01 ; * * * P<0.00 \mathrm{I})$.

Abbreviations: Au NP, gold nanoparticle; $\mathrm{C}+$, positive control (I0 $\mu \mathrm{M}$ hydrogen peroxide); $\mathrm{C}-$, negative (untreated) control; h, hours; MTT, methylthiazol tetrazolium; PBL, peripheral blood lymphocytes; SEM, standard error of the mean.

$15 \mathrm{~nm} \mathrm{Au} \mathrm{NPs,} \mathrm{but} 15 \mathrm{~nm} \mathrm{Au} \mathrm{NPs} \mathrm{was} \mathrm{the} \mathrm{most} \mathrm{effective}$ at $100 \mu \mathrm{g} / \mathrm{mL}$.

In Raw264.7 cells, proliferation decreased after exposure to both Au NPs, and the effect was dose dependent in the presence of $5 \mathrm{~nm}$ Au NPs. The clearest low-dose effect was seen following exposure to $5 \mathrm{~nm} \mathrm{Au} \mathrm{NPs.} \mathrm{Although}$ no significant dose-response was observed, the highest dose $(100 \mu \mathrm{g} / \mathrm{mL})$ of $15 \mathrm{~nm}$ Au NPs resulted in illegible slides because of the lack of morphologically undamaged cells (Table 2). Concentration-dependent decrease in the mitotic index was noticed, and the inhibition of cell division occurred more significantly in macrophages exposed to $15 \mathrm{~nm} \mathrm{Au} \mathrm{NPs.} \mathrm{The} \mathrm{apoptotic} \mathrm{index} \mathrm{was} \mathrm{significantly}$ increased at the highest $5 \mathrm{~nm}$ and $15 \mathrm{~nm} \mathrm{Au} \mathrm{NPs} \mathrm{con-}$ centrations, and in a dose-dependent manner with $15 \mathrm{~nm}$ Au NPs. While $15 \mathrm{~nm}$ Au NPs induced a dose-dependent effect, $5 \mathrm{~nm} \mathrm{Au} \mathrm{NPs} \mathrm{increased} \mathrm{the} \mathrm{necrotic} \mathrm{index} \mathrm{at} \mathrm{all}$ tested concentrations.

Table 2 Cytostasis and cytotoxicity evaluated by CBMN Cyt assay

\begin{tabular}{|c|c|c|c|c|c|c|c|c|}
\hline & \multicolumn{2}{|l|}{ CBPI } & \multicolumn{2}{|c|}{ Mitotic index } & \multicolumn{2}{|c|}{ Apoptotic index } & \multicolumn{2}{|c|}{ Necrotic index } \\
\hline & PBL & Raw264.7 & PBL & Raw264.7 & PBL & Raw264.7 & PBL & Raw264.7 \\
\hline $\mathrm{C}_{-}$ & $1.88 \pm 0.02$ & $1.85 \pm 0.04$ & $6.5 \pm 0.1$ & $5.6 \pm 0.2$ & $0.7 \pm 0.1$ & $1.7 \pm 0.2$ & $0.2 \pm 0.2$ & $0.9 \pm 0.3$ \\
\hline $\mathrm{C}+$ & $1.17 \pm 0.13 * * *$ & $1.4 \mathrm{I} \pm 0.06^{* * *}$ & $0.3 \pm 0.2^{* * *}$ & $2.3 \pm 0.6 * * *$ & $4.7 \pm 0.3^{* * *}$ & $4.6 \pm 0.5 * * *$ & $2.5 \pm 0.4 * * *$ & $4.0 \pm 0.4$ \\
\hline \multicolumn{9}{|l|}{ Au NP $5 \mathrm{~nm}$} \\
\hline $0.1 \mu \mathrm{g} / \mathrm{mL}$ & $1.55 \pm 0.02 * * *$ & $1.62 \pm 0.06 * *$ & $3.9 \pm 0.2 * * *$ & $4.0 \pm 0.4 * * *$ & $1.2 \pm 0.2 *$ & $2.0 \pm 0.5$ & $1.6 \pm 0.3 * * *$ & $3.4 \pm 0.4^{* * *}$ \\
\hline $\mathrm{I} \mu \mathrm{g} / \mathrm{mL}$ & $1.54 \pm 0.05 * * *$ & $1.62 \pm 0.05 * *$ & $4.6 \pm 0.6 * *$ & $3.9 \pm 0.4 * * *$ & $1.9 \pm 0.5 * *$ & $1.2 \pm 0.3$ & $2.4 \pm 0.3 * * *$ & $2.1 \pm 0.5^{* *}$ \\
\hline $10 \mu \mathrm{g} / \mathrm{mL}$ & $1.47 \pm 0.02 * * *$ & $1.57 \pm 0.05 * *$ & $4.4 \pm 0.3^{* * * *}$ & $3.6 \pm 0.3 * * *$ & $1.6 \pm 0.2^{* *}$ & $1.8 \pm 0.5$ & $2.6 \pm 0.2 * * *$ & $2.9 \pm 0.2^{* * *}$ \\
\hline $100 \mu \mathrm{g} / \mathrm{mL}$ & $1.36 \pm 0.05 * * *$ & $\mid .5 I \pm 0.07 * * *$ & $2.8 \pm 0.4^{* * *}$ & $3.1 \pm 0.4 * * *$ & $1.8 \pm 0.4^{* *}$ & $2.6 \pm 0.2 * * *$ & $3.0 \pm 0.6 * * *$ & $4.3 \pm 0.6 * * *$ \\
\hline \multicolumn{9}{|l|}{ Au NP I 5 nm } \\
\hline $0.1 \mu \mathrm{g} / \mathrm{mL}$ & $1.70 \pm 0.03 *$ & $1.68 \pm 0.04 * *$ & $4.9 \pm 0.5^{* *}$ & $3.7 \pm 0.3 * * *$ & $1.5 \pm 0.1 * *$ & $1.7 \pm 0.1$ & $0.6 \pm 0.2 *$ & $1.4 \pm 0.2^{*}$ \\
\hline $\mathrm{I} \mu g / \mathrm{mL}$ & $1.57 \pm 0.02 * * *$ & $1.6 \mathrm{I} \pm 0.01 * * *$ & $4.0 \pm 0.6 * * *$ & $2.8 \pm 0.2 * * *$ & $1.9 \pm 0.2 * *$ & $2.3 \pm 0.3^{*}$ & $0.9 \pm 0.1 * *$ & $\mathrm{I} .7 \pm 0.3 * *$ \\
\hline $10 \mu \mathrm{g} / \mathrm{mL}$ & $1.56 \pm 0.05 * * *$ & $1.60 \pm 0.04 * * *$ & $3.5 \pm 0.3 * * *$ & $2.5 \pm 0.2 * * *$ & $3.5 \pm 0.3 * * *$ & $2.8 \pm 0.4^{* *}$ & $1.6 \pm 0.2 * * *$ & $2.5 \pm 0.3 * * *$ \\
\hline $100 \mu \mathrm{g} / \mathrm{mL}$ & $1.34 \pm 0.04 * * *$ & Toxic & $1.1 \pm 0.6 * * *$ & Toxic & $9.1 \pm 0.2^{* * *}$ & Toxic & $3.7 \pm 0.6 * * *$ & Toxic \\
\hline
\end{tabular}

Notes: CBPI and mitotic (cytostasis), apoptotic, and necrotic (cytotoxicity) indices scored by CBMN Cyt assay. CBPI of PBL exposed to $5 \mathrm{~nm}$ and I5 nm Au NPs decreased with a dose-dependent relationship ( $P=0.027$ and $P=0.02$, respectively) as well as for Raw264.7 exposed to $5 \mathrm{~nm}$ Au NPs ( $P=0.04$ ). Dose-dependent decrease in the mitotic index was observed in PBL exposed to $15 \mathrm{~nm}$ Au NPs $(P=0.029)$ and in Raw264.7 exposed to $5 \mathrm{~nm}$ and $15 \mathrm{~nm}$ Au NPs $(P=0.033$ and $P=0.05$, respectively). Both PBL and Raw264.7 exposed to $15 \mathrm{~nm}$ Au NPs showed dose-dependent apoptotic index increase ( $P=0.049$ and $P=0.05$, respectively); the necrotic index induced a dose-dependent effect in PBL exposed to $5 \mathrm{~nm}$ and $15 \mathrm{~nm}$ Au NPs ( $P=0.016$ and $P=0.03$, respectively) and in Raw264.7 exposed to $15 \mathrm{~nm}$ Au NPs $(P=0.017)$. $100 \mu \mathrm{g} / \mathrm{mL} 15 \mathrm{~nm}$ Au NPs resulted in illegible slides. Statistically significant differences from the control were determined by the Student's $t$-test $(* P<0.05$; $* * P<0.01 ; * * * P<0.00 \mathrm{I})$. Data represent the mean \pm SEM. PBL: $n=4$; Raw264.7: $n=6$.

Abbreviations: Au NP, gold nanoparticle; C+, positive control (0.I $\mu \mathrm{g} / \mathrm{mL}$ MMC); C-, negative (untreated) control; CBMN Cyt, cytokinesis-block micronucleus cytome; $\mathrm{CBPI}$, cytokinesis block proliferation index; MMC, mitomycin C; PBL, peripheral blood lymphocytes; SEM, standard error of the mean. 


\section{Chromosomal damage}

The results of MN, NPB, and NBUD frequencies are summarized in Table 3. The frequency of $\mathrm{MN}$ in PBL increased dose-dependently up to 3.8-fold and 6.9-fold after exposure to $5 \mathrm{~nm}$ and $15 \mathrm{~nm}$ Au NPs, respectively, while the number of MN increased up to 3.2-fold and 11.9-fold when Raw264.7 were treated with $5 \mathrm{~nm}$ and $15 \mathrm{~nm}$ Au NPs; $15 \mathrm{~nm}$ Au NPs showed a dose-dependent relationship in Raw264.7. In both cell types, a more severe $\mathrm{MN}$ induction was observed after treatment with $15 \mathrm{~nm} \mathrm{Au} \mathrm{NPs.} \mathrm{Chromosome} \mathrm{rearrange-}$ ments, detected as NPB formation, were more pronounced in PBL than in Raw264.7. Furthermore, in PBL following $5 \mathrm{~nm}$ Au NPs exposure and for both sets of Au NPs delivered to Raw264.7, the ratio NPB/MN showed that the lowest dose $(0.1 \mu \mathrm{g} / \mathrm{mL})$ exhibited higher chromosome breakage than $100 \mu \mathrm{g} / \mathrm{mL}$. The frequencies of NBUD, biomarker of amplified DNA elimination, increased more in lymphocytes than in macrophages exposed to $5 \mathrm{~nm} \mathrm{Au} \mathrm{NPs,} \mathrm{while} \mathrm{after}$ exposure to $15 \mathrm{~nm} \mathrm{Au} \mathrm{NPs} \mathrm{the} \mathrm{macrophages} \mathrm{were} \mathrm{more}$ sensitive than lymphocytes.

Taken together, these data indicate that $15 \mathrm{~nm} \mathrm{Au} \mathrm{NPs}$ induced more significant chromosomal damage than $5 \mathrm{~nm}$ Au NPs.

\section{FISH analysis}

The exposure to $\mathrm{Au}$ NPs induced significant increase in centromere-positive MN formation in both cell types, indicating the induction of chromosome segregation anomalies rather than clastogenic effects (Figure 2). Both the Au NPs induced higher chromosome loss in PBL than in Raw264.7; however, in PBL the lowest dose of $5 \mathrm{~nm} \mathrm{Au} \mathrm{NPs} \mathrm{showed}$ minor, but still significant, aneuploidogenic effects. Raw264.7 cells showed no significant aneuploidogenic events at the lowest $5 \mathrm{~nm}$ Au NPs dose, while $15 \mathrm{~nm} \mathrm{Au} \mathrm{NPs}$ induced linear dose-dependent effects.

\section{DNA strand breaks}

Figure 3 shows the data obtained evaluating the Au NPsinduced DNA damage by the comet assay. Significant increase in DNA migration was detected after 2 hours and 24 hours of exposure in both cell types, and the increase was dose dependent with the exception of PBL exposed for 24 hours to $5 \mathrm{~nm} \mathrm{Au} \mathrm{NPs.}$

PBL were more sensitive to $5 \mathrm{~nm}$ and $15 \mathrm{~nm} \mathrm{Au} \mathrm{NPs}$ than Raw264.7: at $100 \mu \mathrm{g} / \mathrm{mL}$, in fact, a 3.6-fold and 2.7-fold increase in DNA damage was observed following 24 hours of exposure to $5 \mathrm{~nm}$ Au NPs in PBL and Raw264.7, respectively. Accordingly, when exposed to $15 \mathrm{~nm}$ Au NPs for 24 hours, PBL were more sensitive than Raw264.7, presenting respectively up to 4.7-fold and 2.7-fold increases in DNA strand breaks. Interestingly, at 2 hours of exposure, PBL were more sensitive to $5 \mathrm{~nm} \mathrm{Au} \mathrm{NPs} \mathrm{than} 15 \mathrm{~nm} \mathrm{Au}$ NPs, while after 24 hours of exposure to the highest doses, the opposite was observed.

\section{Oxidative DNA damage}

By using the repair enzymes EndoIII and Fpg, the oxidative DNA damage was investigated at 2 hours and

Table 3 Genotoxicity evaluated by CBMN Cyt assay in PBL and Raw264.7 cells exposed to increasing mass concentrations of Au NPs

\begin{tabular}{|c|c|c|c|c|c|c|}
\hline & \multicolumn{2}{|l|}{$\mathbf{M N}$} & \multicolumn{2}{|l|}{ NPB } & \multicolumn{2}{|l|}{ NBUD } \\
\hline & PBL & Raw264.7 & PBL & Raw264.7 & PBL & Raw264.7 \\
\hline $\mathrm{C}_{-}$ & $3.25 \pm 0.75$ & $2.3 \pm 0.5$ & $0.5 \pm 0.5$ & I. $2 \pm 0.4$ & $0 \pm 0$ & $0.5 \pm 0.5$ \\
\hline $\mathrm{C}+$ & $43.3 \pm 7.2^{* * *}$ & $32.4 \pm 5.6 * * *$ & $14.4 \pm 0.8^{* * *}$ & $13.4 \pm 1.0 * *$ & $2.8 \pm 0.5^{* * *}$ & $7.0 \pm 1.5^{* * *}$ \\
\hline \multicolumn{7}{|l|}{ Au NP $5 \mathrm{~nm}$} \\
\hline $0.1 \mu g / m L$ & $5.0 \pm 1.4$ & $5.1 \pm 1.1$ & $2.2 \pm 0.5^{* *}$ & $1.8 \pm 0.5$ & $1.5 \pm 0.5^{* *}$ & $1.3 \pm 0.6$ \\
\hline $\mathrm{I} \mu \mathrm{g} / \mathrm{mL}$ & $7.0 \pm 2.0$ & $4.5 \pm 1.2$ & $2.2 \pm 0.2 * *$ & $1.4 \pm 0.8$ & $4.3 \pm 0.3 * * *$ & $1.0 \pm 0.8$ \\
\hline $10 \mu \mathrm{g} / \mathrm{mL}$ & $8.5 \pm 0.35^{*}$ & $5.4 \pm 1.4$ & $2.0 \pm 0.4^{* *}$ & $1.4 \pm 0.8$ & $2.5 \pm 0.4 * * *$ & $2.0 \pm 0.8$ \\
\hline $100 \mu \mathrm{g} / \mathrm{mL}$ & $12.5 \pm 0.35 * *$ & $7.4 \pm 1.1 * *$ & $3.2 \pm 0.6 * *$ & $1.8 \pm 0.4$ & $6.7 \pm 0.9 * * *$ & $1.3 \pm 0.4$ \\
\hline \multicolumn{7}{|l|}{ Au NP I $5 \mathrm{~nm}$} \\
\hline $0.1 \mu \mathrm{g} / \mathrm{mL}$ & $9.2 \pm 1.2^{*}$ & $17.5 \pm 1.5 * *$ & $2.0 \pm 0.5^{* *}$ & $4.2 \pm 1.2 *$ & $0.5 \pm 0.5$ & $5.5 \pm 0.5^{* * *}$ \\
\hline $\mathrm{I} \mu \mathrm{g} / \mathrm{mL}$ & $12.5 \pm 0.5 * *$ & $25.0 \pm 2.0 * * *$ & $2.8 \pm 0.7^{* *}$ & $4.8 \pm 0.5^{*}$ & $2.5 \pm 0.5^{* * *}$ & $7.0 \pm 1.0 * * *$ \\
\hline $10 \mu g / m L$ & $14.3 \pm 1.2^{* *}$ & $27.5 \pm 2.5 * * *$ & $2.8 \pm 1.0 * *$ & $4.8 \pm 0.8 *$ & $5.5 \pm 0.7 * * *$ & $7.5 \pm 1.5^{* * *}$ \\
\hline $100 \mu \mathrm{g} / \mathrm{mL}$ & $22.4 \pm 2.3^{* * *}$ & Toxic & $3.2 \pm 1.5^{* *}$ & Toxic & $12 \pm 1 * * *$ & Toxic \\
\hline
\end{tabular}

Notes: MN, NPB, and NBUD frequencies scored by CBMN Cyt assay after exposure of PBL and Raw264.7 to increasing mass concentrations of Au NPs (0.I-I00 $\mu g / m L)$. In PBL, $5 \mathrm{~nm}$ and $15 \mathrm{~nm}$ Au NPs induced dose-dependent effect in MN ( $P=0.0014$ and $P=0.03$, respectively), NPB ( $P=0.012$ and $P=0.033$; respectively), and NBUD frequency $(P=0.05$ and $P=0.02$, respectively). MN frequency of Raw264.7 exposed to $15 \mathrm{~nm}$ Au NPs showed a dose-dependent relationship ( $P=0.05)$. Statistically significant differences from the control were determined by the Student's $t$-test ( $* P<0.05 ; * * P<0.01$; *** $P<0.00$ I). Data represent the mean $\pm S E M(P B L: n=4 ; R a w 264.7: n=6)$.

Abbreviations: Au NP, gold nanoparticle; C+, positive control (0.1 $\mu \mathrm{g} / \mathrm{mL}$ mitomycin C); C-, negative (untreated) control; CBMN Cyt, cytokinesis-block micronucleus cytome; MN, micronuclei; NBUD, nuclear buds; NPB, nucleoplasmic bridges; PBL, peripheral blood lymphocytes; SEM, standard error of the mean. 

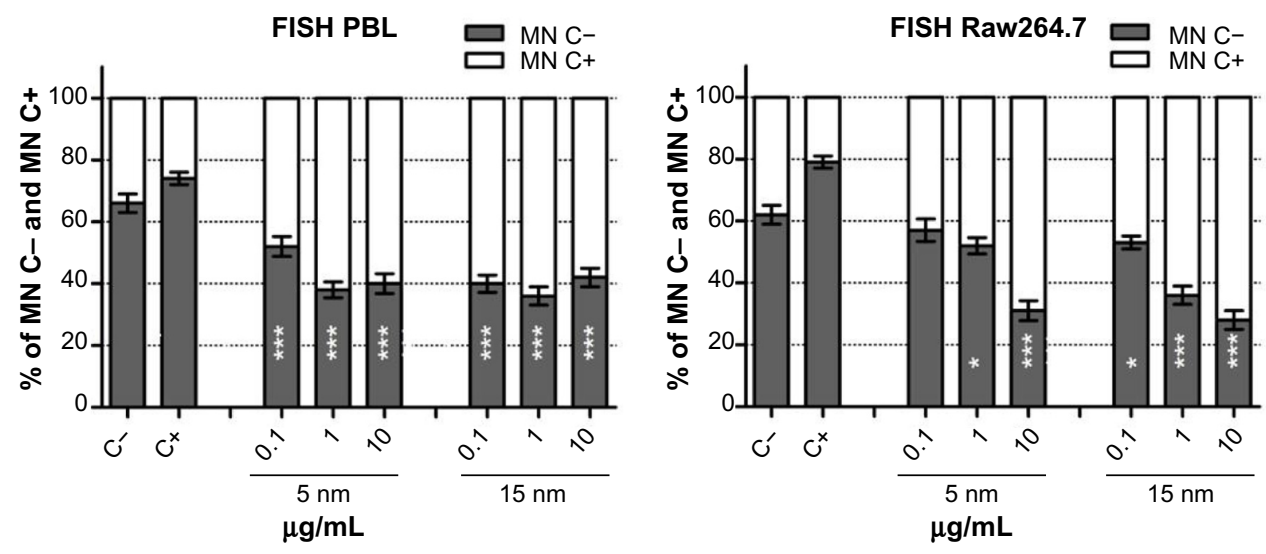

Figure 2 FISH analysis in PBL and Raw264.7 after exposure to $5 \mathrm{~nm}$ and $15 \mathrm{~nm}$ Au NPs.

Notes: Using pancentromeric probes applied to the CBMN Cyt slides, the centromeric spots were analyzed and the exposure of Raw264.7 to I5 nm Au NPs showed dosedependent $(P=0.01)$ aneuploidogenic events. Data are shown as mean \pm SEM (PBL: $n=4 ;$ Raw264.7: $n=6)$. Student's $t$-test: $* P<0.05 ; * * P<0.01 ; * * * P<0.001$.

Abbreviations: Au NP, gold nanoparticle; C+, positive control (MMC $0.1 \mu \mathrm{g} / \mathrm{mL}$ ); C-, negative (untreated) control; CBMN Cyt, cytokinesis-block micronucleus cytome; $\mathrm{FISH}$, fluorescence in situ hybridization; h, hours; MN C+, micronuclei centromere +ve; MN C-, micronuclei centromere -ve; PBL, peripheral blood lymphocytes; SEM, standard error of the mean.

24 hours exposure, and oxidized pyrimidines were detected in both cell systems by the presence of EndoIII sensitive DNA sites (Figure 4). Compared to PBL, at 2 hours of exposure Raw264.7 were particularly susceptible, showing a dose-dependent pyrimidines oxidation in the presence of $15 \mathrm{~nm} \mathrm{Au} \mathrm{NPs}$; interestingly, the $5 \mathrm{~nm}$ $\mathrm{Au}$ NPs treatments were the less damaging to Raw264.7 and most harmful to PBL. After 24 hours of treatment, in both cell types the two Au NPs induced oxidized pyrimidines in a dose-dependent way; Raw264.7 were more sensitive than PBL (4.2-fold and 7.8-fold increases in Raw264.7 and 2.9-fold and 3.3-fold increases in PBL

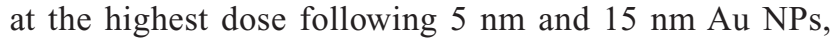
respectively).

Raw264.7 were more sensitive in detecting oxidized purines by Fpg restriction enzyme: $5 \mathrm{~nm}$ Au NPs at 2 hours of exposure induced a 4.8-fold increase in Raw264.7 and 3.9 in PBL. Similarly, after 24 hours of exposure, in Raw264.7 the purines oxidation increased 4.1-fold, while in PBL the increase was up to 1.5-fold. At 2 hours of exposure to $15 \mathrm{~nm}$ Au NPs, purines oxidation was up to eight times higher in Raw264.7 and up to four times higher in PBL compared to negative control, while at 24 hours of exposure the oxidative damage was up to seven times higher in Raw264.7 and 2.3 times in PBL.
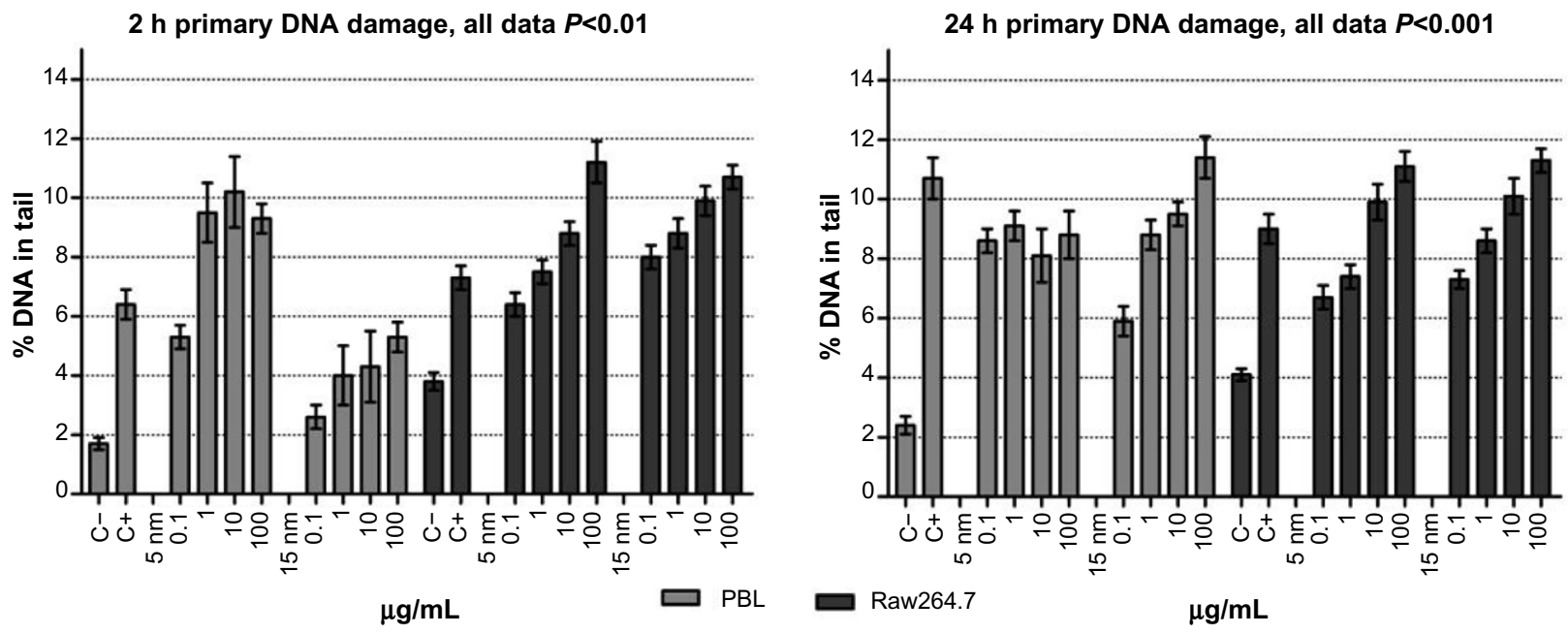

Figure 3 Comet assay to evaluate primary DNA damage/breakage effects in PBL and Raw264.7.

Notes: The 2-hour treatments with $5 \mathrm{~nm}$ and $15 \mathrm{~nm}$ Au NPs showed a dose-effect relationship in $P B L(P=0.05$ and $P=0.002)$ and in Raw264.7 ( $P=0.0014$ and $P=0.03$, respectively). The 24-hour exposure to $5 \mathrm{~nm}$ and $15 \mathrm{~nm}$ Au NPs showed a dose-effect relationship in Raw264.7 ( $P=0.0016$ and $P=0.004$, respectively), but only I5 nm Au NPs in PBL $(P=0.006)$. Data are shown as mean \pm SEM (PBL: $n=4$; Raw264.7: $n=6$ ) of percent DNA in tail. Student's $t$-test: 2 -hour data, $P<0.0$ l; 24 -hour data, $P<0.00$ I.

Abbreviations: Au NP, gold nanoparticle; C+, positive control (I0 $\mu$ M hydrogen peroxide); C-, negative (untreated) control; DNA, deoxyribonucleic acid; h, hours; PBL, peripheral blood lymphocytes; SEM, standard error of the mean. 
$2 \mathrm{~h}$ pyrimidine oxidation

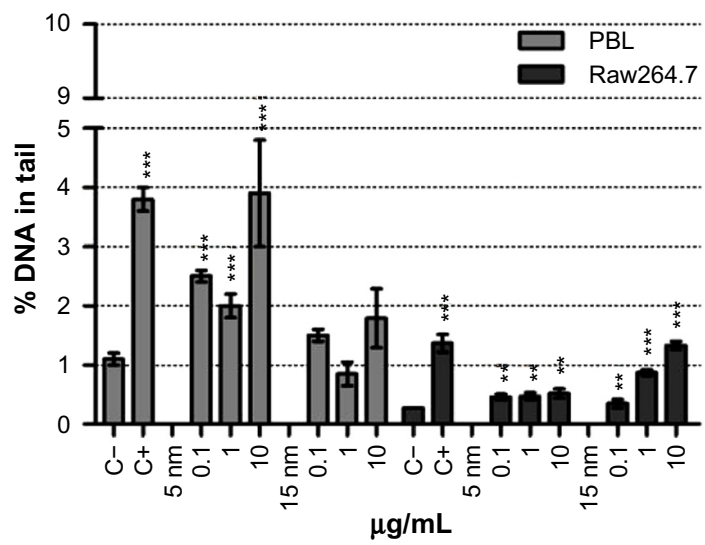

$24 \mathrm{~h}$ pyrimidine oxidation

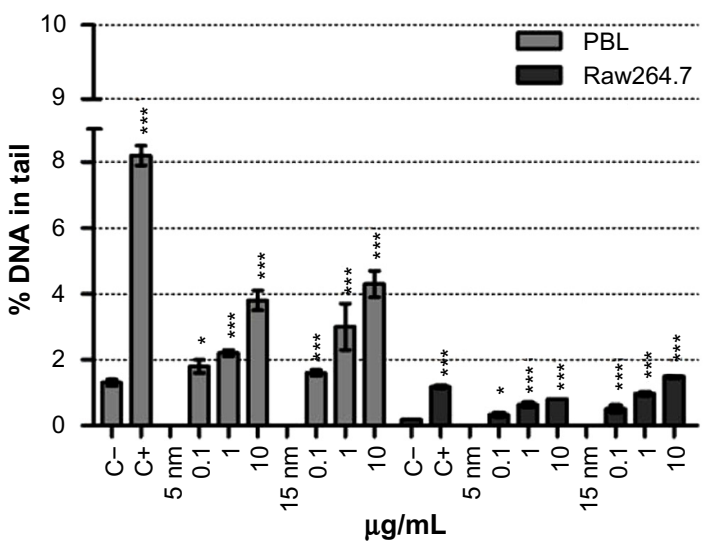

$2 \mathrm{~h}$ purine oxidation, all data $P<0.05$

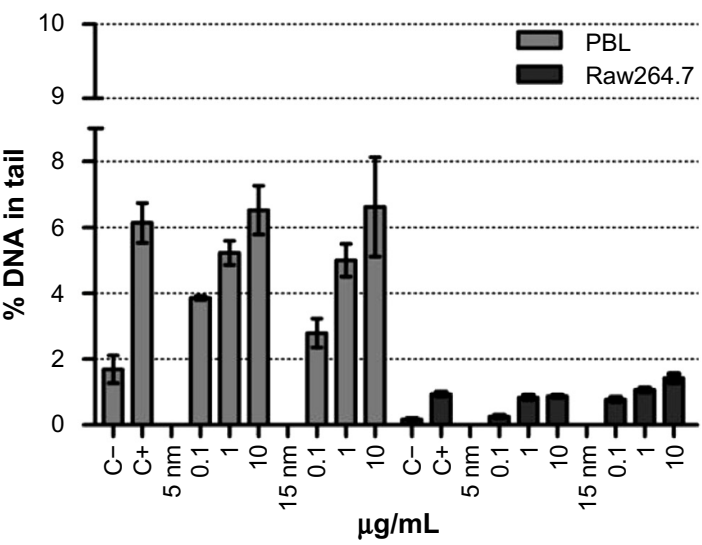

24 h purine oxidation, all data $P<0.05$

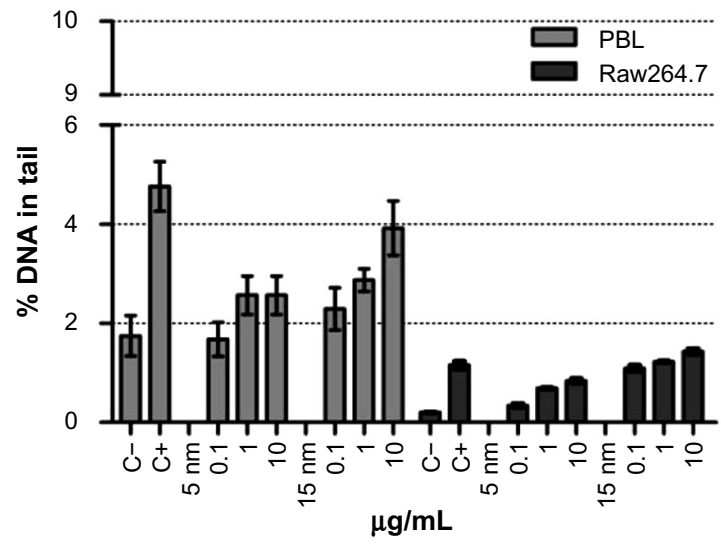

Figure 4 Oxidative DNA damage evaluated using the enzyme-modified comet assay in PBL and Raw264.7.

Notes: Dose-dependent pyrimidines oxidation was detected in PBL after 24 hours of exposure to $5 \mathrm{~nm}$ and I $5 \mathrm{~nm}$ Au NPs ( $P=0.05$ and $P=0.028$, respectively). In Raw264.7 the pyrimidines oxidation, detected by the Endolll enzyme, showed a dose-dependent effect after 2 hours of exposure to $15 \mathrm{~nm}$ Au NPs ( $P=0.035$ ) and at 24 hours to $5 \mathrm{~nm}$ and $15 \mathrm{~nm}$ Au NPs ( $P=0.009$ and $P=0.006$, respectively). By Fpg, dose-dependent purines oxidation was observed in PBL after 2 hours of exposure to $5 \mathrm{~nm}$ and $15 \mathrm{~nm}$ Au NPs $(P=0.009$ and $P=0.007$, respectively), as well as after 24 hours of exposure to $5 \mathrm{~nm}$ Au NPs $(P=0.014)$. In Raw264.7, a dose-effect relationship was detected following 2 hours of exposure to $15 \mathrm{~nm}$ Au NPs $(P=0.01)$ and 24 hours of incubation in the presence of $5 \mathrm{~nm}$ Au NPs $(P=0.015)$. Data are shown as mean \pm SEM (PBL: $\mathrm{n}=4$; Raw264.7: $\mathrm{n}=6$ ) of percent DNA in tail. Student's $t$-test: $* \mathrm{P}<0.05$; $* * \mathrm{P}<0.0 \mathrm{I} ; * * * \mathrm{P}<0.00 \mathrm{I}$.

Abbreviations: Au NP, gold nanoparticle; C+, positive control (I0 $\mu \mathrm{M}$ hydrogen peroxide); C-, negative (untreated) control; DNA, deoxyribonucleic acid; Endolll, endonuclease-III; Fpg, formamidopyrimidine-DNA glycosylase; h, hours; PBL, peripheral blood lymphocytes; SEM, standard error of the mean.

\section{Comparison between mass} concentrations and numbers of Au NPs

Data obtained by mass concentration exposure indicate that the particle size plays a role in determining cytotoxicity and genotoxicity. However, the same mass concentration of $5 \mathrm{~nm}$ and $15 \mathrm{~nm}$ Au NPs corresponds to different absolute particle numbers. Consequently, if mass concentrations are expressed as theoretically calculated numbers of Au NPs, MTT assay excludes a size-dependent effect on the cell viability (Figure S1). Following this approach, by MTT the same theoretical number of Au NPs showed cytotoxic effects on PBL and Raw264.7 independently of the dimension. To further evaluate the importance of size in determining cytotoxicity, CBPI was analyzed taking into account the number of Au NPs theoretically calculated from the given mass concentrations and showed size-independent antiproliferative effects (Figure S2A and B). In contrast, in both cell types the more severe $\mathrm{MN}$ induction was observed after the treatments with $15 \mathrm{~nm}$ Au NPs either considering the given mass concentrations (Table 3 ) or the theoretically calculated particle numbers (Figure S2C and D).

To verify these indications, exposures to Raw 264.7 cells were carried out by controlling the effective number of $\mathrm{Au}$ NPs, ranging from $1 \times 10^{9}$ to $1 \times 10^{11}$, that corresponds to different mass concentrations (Au NP $5 \mathrm{~nm}$ : from 0.00126 to $0.126 \mu \mathrm{g} / \mathrm{mL}$; Au NP $15 \mathrm{~nm}$ : from 0.034 to $3.4 \mu \mathrm{g} / \mathrm{mL}$ ). By MTT the size-independent effects exerted by absolute numbers of $5 \mathrm{~nm}$ and $15 \mathrm{~nm}$ Au NPs on the viability of Raw 264.7 cells, both after 2 hours and 24 hours of exposure, were confirmed (Figure 5). CBMN Cyt showed that Au NPs 

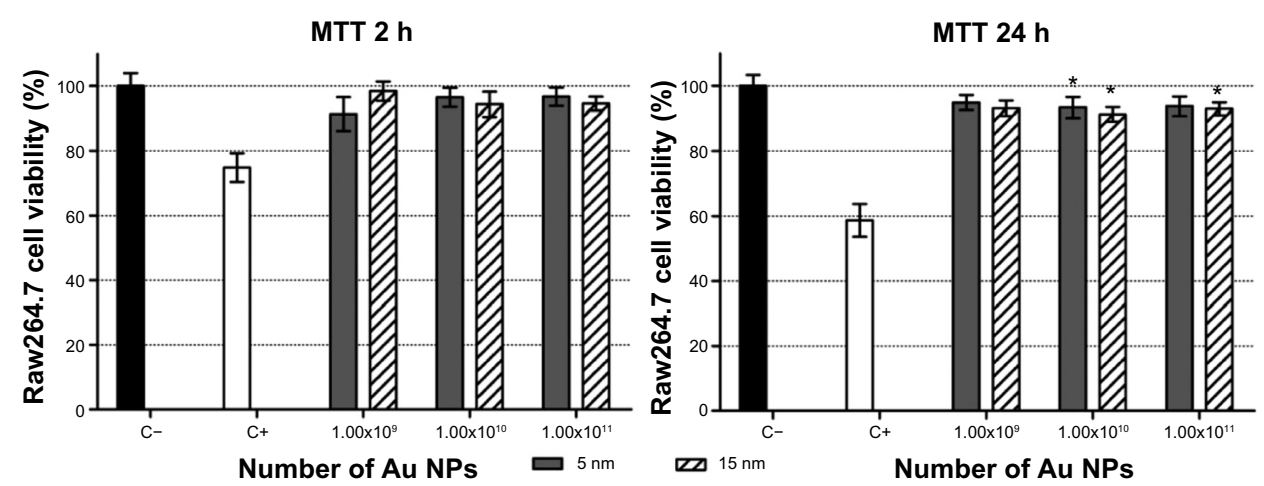

Figure 5 Cell viability in Raw264.7 after 2 hours and 24 hours of exposure to absolute numbers of 5 nm and I5 nm Au NPs.

Notes: Cells were exposed to $1.00 \times 10^{9}, 1.00 \times 10^{10}$, and $1.00 \times 10^{11}$ Au NPs and evaluated by MTT assay. The data show the percent of living cells normalized to untreated control $( \pm S E M, n=9)$. Statistically significant differences from the $C$ - were determined by the Student's $t$-test $(* P<0.05)$. There were no statistically significant differences between the same number of $5 \mathrm{~nm}$ and $15 \mathrm{~nm}$ Au NPs.

Abbreviations: Au NP, gold nanoparticle; C+, positive control (10 $\mu$ M hydrogen peroxide); C-, negative (untreated) control; h, hours; MTT, methylthiazol tetrazolium; SEM, standard error of the mean.

decreased the proliferation of Raw264.7 cells without statistically significant size effect, while significant differences in genotoxicity and especially in MN induction were found (Table 4). In fact, $\mathrm{MN}$ frequencies after exposure to $15 \mathrm{~nm}$ Au NPs showed a dose-dependent relationship and differed significantly from $5 \mathrm{~nm}$ Au NPs. NPB and NBUD increased in a particle number-dependent way, but only the response obtained with the highest $15 \mathrm{~nm}$ Au NPs dose differed significantly from the negative control, and the effects of 15 $\mathrm{nm} \mathrm{Au}$ NPs were more severe than the damage induced by $5 \mathrm{~nm} \mathrm{Au} \mathrm{NPs.}$

Table 4 Proliferation and genotoxicity evaluated by CBMN Cyt assay in Raw264.7 cells exposed to an absolute number of Au NPs

\begin{tabular}{lllll}
\hline & CBPI & MN & NPB & NBUD \\
\hline C- & $1.810 \pm 0.017$ & $2.3 \pm 0.3$ & $1.0 \pm 0.4$ & $0.8 \pm 0.4$ \\
C & $1.295 \pm 0.046^{* * *}$ & $28.7 \pm 2.4^{* * *}$ & $5.8 \pm 0.8^{* * *}$ & $6.2 \pm 0.6^{* * *}$ \\
Au NP 5 nm & & & & \\
$\quad I \times 10^{9}$ & $1.681 \pm 0.005^{* *}$ & $4.3 \pm 0.7$ & $1.0 \pm 0.4$ & $0.8 \pm 0.4$ \\
$\quad I \times 10^{10}$ & $1.673 \pm 0.013^{* *}$ & $3.7 \pm 0.3^{*, a}$ & $1.3 \pm 0.4$ & $1.2 \pm 0.2$ \\
$\quad I \times 10^{11}$ & $1.661 \pm 0.014^{* *}$ & $4.7 \pm 0.3^{* *, a}$ & $1.5 \pm 0.3^{\mathrm{a}}$ & $1.0 \pm 0.4^{\mathrm{a}}$ \\
Au NP I5 nm & & & & \\
$\quad I \times 10^{9}$ & $1.678 \pm 0.005^{* *}$ & $6.3 \pm 0.6^{* *}$ & $1.3 \pm 0.2$ & $1.3 \pm 0.2$ \\
$\quad I \times 10^{10}$ & $1.672 \pm 0.011^{* *}$ & $6.0 \pm 0.5^{* *, \mathrm{~b}}$ & $2.0 \pm 0.4$ & $1.8 \pm 0.4$ \\
$\quad I \times 10^{\prime 1}$ & $1.665 \pm 0.021^{* *}$ & $9.3 \pm 1.2^{* *, \mathrm{~b}}$ & $2.3 \pm 0.2^{*, \mathrm{~b}}$ & $2.3 \pm 0.2^{*, \mathrm{~b}}$ \\
\hline
\end{tabular}

Notes: CBPI, MN, NPB, and NBUD frequencies scored by CBMN Cyt assay after Raw264.7 cells exposed to absolute Au NPs numbers. MN frequency in Raw264.7 exposed to $15 \mathrm{~nm}$ Au NPs showed a dose-dependent relationship ( $P=0.008)$, as well as the NPB after exposure to $5 \mathrm{~nm}$ and $15 \mathrm{~nm}$ Au NPs $(P=0.05$ and $P=0.02)$. Dosedependent NBUD formation was scored in the presence of $15 \mathrm{~nm}$ Au NPs $(P=0.008)$. Statistically significant differences from $C$ - were determined by the Student's $t$-test $(* P<0.05 ; * * P<0.01$; $* * * P<0.001$ ), as well as the differences between respective tested conditions ( $P<0.05$ versus $15 \mathrm{~nm}$ Au NPs; ${ }^{\circ} P<0.05$ versus $5 \mathrm{~nm}$ Au NPs). Data represent the mean $\pm \operatorname{SEM}(n=6)$.

Abbreviations: Au NP, gold nanoparticle; $C_{+}$, positive control $(0.1 \mu g / \mathrm{mL}$ mitomycin C); C-, negative (untreated) control; CBMN Cyt, cytokinesis-block micronucleus cytome; MN, micronuclei; NBUD, nuclear buds; NPB, nucleoplasmic bridges; PBL, peripheral blood lymphocytes; SEM, standard error of the mean.

\section{Discussion}

Our results suggest that $\mathrm{Au}$ NPs of different size $(5 \mathrm{~nm}$ and $15 \mathrm{~nm}$ ) can induce inhibition of cell proliferation mediated by apoptosis, as well as chromosomal damage, aneuploidogenic events, DNA strand breaks, pyrimidines and purines oxidative lesions in human PBL and in a murine macrophage cell line. The chromosomal damage was more severe in Raw264.7 macrophages exposed to $15 \mathrm{~nm} \mathrm{Au} \mathrm{NPs,} \mathrm{and} \mathrm{over-}$ all both Au NPs induced dose-dependent genotoxic effects. Aneuploidy was induced irrespective of the Au NPs size, and the lymphocytes showed a relatively higher percentage of chromosome mis-segregation than macrophages. PBL showed higher DNA strand breaks than Raw264.7, while the macrophages were more sensitive to pyrimidines and purines oxidation. Moreover, our data allowed a correlation between the cytotoxic mechanisms assessed with the tested mass concentration and the absolute number of $\mathrm{Au}$ NPs, showing a size-independent relationship. The size of Au NPs, on the other hand, played an important role in determining genotoxic effects in PBL and Raw264.7 cells.

Recent reports on the reactivity of Au NPs focused on their effects on biocompatibility, uptake, toxicity, and mutagenic effects. ${ }^{26-30}$ However, in general, there is a lack of conclusive information on the size as the key factor for $\mathrm{Au}$ NPs cytotoxicity and genotoxicity, and on the relationship between size, mass concentration and the absolute particle number.

The cytotoxicity of Au NPs on A549 and NCIH441 cell lines was described, suggesting that the presence of sodium citrate can affect the cell viability and proliferation rather than the size of the particles, which appears to have no effect on active Au NPs endocytosis. ${ }^{6}$ Accordingly, it was shown that not the size of the Au NPs, but the amount of citrate on the 
particle surface impaired the viability of the endothelial cells HDMEC and hCMEC, which, in addition, exhibited different uptake behavior for citrate-stabilized gold nanoparticles. ${ }^{7}$ In contrast, the uptake of Au NPs coated with nucleic acid and polyethyleneimine into mammalian cells demonstrated that changes in the nanoparticle size can lead to significant differences in the number of molecules delivered per cell. ${ }^{31}$ Furthermore, the uptake efficiency and the intracellular localization of Au NP-peptide conjugates was shown being directly dependent on the peptide itself, and the intracellular destination was shown to be further determined by Au NP size. ${ }^{32} \mathrm{Au}$ NPs size-dependent bioaccumulation and (eco) toxicity has been demonstrated by metallothionein induction, increased activities of catalase, superoxide dismutase and glutathione S-transferase by three sizes of citrated-coated Au NPs $(5,15,40 \mathrm{~nm})$ in Scrobicularia plana, indicating the activation of response to oxidative stress. ${ }^{19}$

Results obtained exposing Balb/3T3 cells to the same citrate-stabilized $5 \mathrm{~nm}$ and $15 \mathrm{~nm}$ Au NPs here investigated revealed cytotoxic effects, measured by colony forming efficiency, for $5 \mathrm{~nm} \mathrm{Au} \mathrm{NPs} \mathrm{but} \mathrm{not} \mathrm{for} 15 \mathrm{~nm} \mathrm{Au}$ NPs. ${ }^{20}$ Coradeghini et al showed also that the changes in cytoskeleton structure of Balb/3T3 cells resulted in pronounced modification of the cell shape and reduction in the expression and degradation of the clathrin heavy chain, but without significant effects in the expression of caveolin. ${ }^{20}$ Citrate-stabilized Au NPs (20 nm) influenced cell cycle pathways in human embryonic lung fibroblasts, reducing the expression of critical checkpoint proteins and causing oxidative stress and alteration of genes associated with genomic stability and DNA repair. ${ }^{33}$ Citrate-stabilized Au NPs downregulated, in a size-dependent manner, cellular responses induced by interleukin 1-beta both in vitro in THP-1 human leukemia monocytic macrophages and in vivo in C57BL/6 male mice. ${ }^{34}$

Nevertheless, the size dependency of adverse effects in human blood is not linear. ${ }^{35}$ Studies with human blood cells showed that $30 \mathrm{~nm}$ Au NPs induced concentration-dependent effects on hemolysis, reactive oxygen species generation, and platelet aggregation. ${ }^{36}$ In addition, studies in mice showed that the bioaccumulation and toxicity of differently sized ( $5 \mathrm{~nm}, 10 \mathrm{~nm}, 30 \mathrm{~nm}$, and $60 \mathrm{~nm}$ ) PEG-coated Au NPs was not size dependent. ${ }^{37}$

In conclusion, both the literature and the results presented in this study demonstrate no clear correlation between the cytotoxicity of differently sized Au NPs and the equivalent spherical diameter. We found that at early time points ( 2 hours), the highest mass concentration of $5 \mathrm{~nm} \mathrm{Au}$
NPs showed a more severe cytotoxicity both in PBL and Raw264.7 compared to the corresponding doses of $15 \mathrm{~nm}$ Au NPs. However, taking into account the theoretically calculated numbers of Au NPs corresponding to the different tested mass concentrations, it was not possible to conclude that $5 \mathrm{~nm} \mathrm{Au} \mathrm{NPs} \mathrm{induced} \mathrm{higher} \mathrm{cytotoxicity} \mathrm{than} 15 \mathrm{~nm}$ Au NPs. These indications were further confirmed by experiments carried out in Raw264.7 cells with a fixed absolute number of differently sized Au NPs.

In addition to size, other physicochemical properties of NPs, such as surface charge, are proposed to be critical determinants of their toxic potential. ${ }^{38,39}$ For instance, the evaluation of differently charged Au NPs (neutral, positively, and negatively charged) in a human keratinocyte cell line (HaCaT) showed that the cell morphology was disrupted in a dose-dependent way by all three NPs: the surface charge was the major determinant of the cellular processes, with the charged NPs inducing cell death through apoptosis and neutral Au NPs through necrosis. ${ }^{40}$ However, as highlighted in this paper, the cell type also plays an important role in activating apoptosis: PBL, in fact, showed higher apoptotic responses than Raw264.7 macrophages.

Interestingly, considering both the mass concentrations and the absolute number of Au NPs, from our study it is clear that the size of Au NPs plays an important role in determining genotoxic mechanisms, although in a nonlinear manner. Both cell systems were more sensitive to $15 \mathrm{~nm} \mathrm{Au}$ NPs than to $5 \mathrm{~nm} \mathrm{Au} \mathrm{NPs,} \mathrm{as} \mathrm{evaluated} \mathrm{through} \mathrm{the} \mathrm{differ-}$ ent biomarkers of chromosomal damage (MN, NPB, and NBUD). The evaluation of the genotoxic effects in Raw264.7 cells, based on the absolute numbers of Au NPs, confirmed nonlinear size-dependent chromosomal damage. However, this result cannot explain the time-dependent primary DNA damage, as the $5 \mathrm{~nm}$ Au NPs were the most harmful both in PBL and in Raw264.7 macrophages. In addition, the lowest dose of $5 \mathrm{~nm} \mathrm{Au} \mathrm{NPs} \mathrm{showed} \mathrm{in} \mathrm{both} \mathrm{cell} \mathrm{types} \mathrm{minor}$ aneuploidogenic effects compared to $15 \mathrm{~nm} \mathrm{Au} \mathrm{NPs,} \mathrm{and} \mathrm{the}$ more clastogenic behavior at low doses was consistent with the described NPB/MN ratio, which provides an important fingerprint for distinguishing the genotoxic mechanisms of different clastogenic and aneuploidogenic agents. ${ }^{41}$

To date, few genotoxicity studies have been performed with $\mathrm{Au}$ NPs. Although minor focal inflammatory changes occurred after a single instillation of $2 \mathrm{~nm}, 20 \mathrm{~nm}$, and 200 $\mathrm{nm} \mathrm{Au}$ NPs into the lung of male adult Wistar rats, genotoxicity was not observed as assessed by the erythrocyte micronucleus test and the comet assay. ${ }^{42}$ In addition, $2 \mathrm{~nm}$, $20 \mathrm{~nm}$, and $200 \mathrm{~nm} \mathrm{Au} \mathrm{NPs}$ failed to induce MN formation in 
human blood and did not damage DNA in the liver and lung of exposed adult male Wistar rats. ${ }^{43}$ The dosing, however, was limited by the stability of the gold suspensions, and Downs et al stated that the results would have looked different upon increasing the gold doses. ${ }^{43}$

Au NPs capped with sodium citrate or polyamidoamine dendrimers interacted with hepatocytes HepG2 and peripheral blood mononuclear cells, and exhibited in vitro cyto- and genotoxicity even at low concentrations. ${ }^{44}$ In zebrafish Danio rerio exposed to low doses of $12 \mathrm{~nm}$ and $50 \mathrm{~nm} \mathrm{Au} \mathrm{NPs,}$ size and exposure length modulated the genotoxicity and the expression of genes involved in DNA repair, apoptosis, and oxidative stress. ${ }^{45}$ Flow cytometry and real-time PCR analysis of apoptotic genes and ATP depletion measurements suggested that $17 \mathrm{~nm} \mathrm{Au} \mathrm{NPs} \mathrm{induced} \mathrm{cell} \mathrm{damage} \mathrm{through}$ extrinsic and intrinsic apoptotic pathways in human lung adenocarcinoma A549 cells. ${ }^{46}$

Au NPs (12 nm) were internalized by the endolysosomal pathway in Balb/3T3 fibroblasts after 10 days of exposure, and although they were not a severe cytotoxicant, Au NPs induced DNA damage. ${ }^{47}$ Moreover, the comet assay showed DNA damage in MRC-5 human lung fibroblasts treated with $20 \mathrm{~nm}$ Au NPs, and FISH analysis revealed that the majority of the chromosomal breaks were undetectable telomeres. ${ }^{48} \mathrm{Li}$ et al explained this genomic instability with the differences in the oxidative stress-related proteins as well as with proteins associated to the cell cycle regulation and cytoskeleton and DNA repair. ${ }^{33}$ Similarly, our studies directly demonstrated that apoptosis, DNA oxidation, and aneuploidy could explain the genotoxicity observed in PBL and Raw264.7 cells. In addition to the alterations of the mitotic spindle, to the weakness of mitotic checkpoints and to cytoskeletal defects, a growing body of evidence suggests that aneuploidy can be also induced by epigenetic mechanisms. ${ }^{49,50}$ Chromatin condensation and reorganization, as well as global gene expression alterations, were observed in fibroblasts exposed to $\mathrm{Au}$ NPs, providing further insights into the molecular mechanisms underlying toxicity of Au NPs and their impact on epigenetic processes. ${ }^{51-53}$

\section{Conclusion}

We can conclude that differently sized Au NPs induced cytotoxicity and genotoxicity through different mechanisms of action. While Au NPs size did not play a pivotal role in determining cytotoxicity, the size was a fundamental factor in inducing genotoxicity. In fact, the most severe genotoxicity in PBL and Raw264.7 was observed following exposure to $15 \mathrm{~nm} \mathrm{Au} \mathrm{NPs.} \mathrm{These} \mathrm{observations} \mathrm{were} \mathrm{confirmed,} \mathrm{also}$ taking into account the particle numbers as dose-metric, and these results might represent groundwork for further studies aimed at investigating the mechanistic interactions between Au NPs and DNA. Nevertheless, cytotoxic and genotoxic mechanisms, as well as the exposure time, could be ascribed to the different cell type-related reactivity. Au NPs induced cytotoxicity through apoptotic pathways, and the premutagenic DNA oxidation appears to be an important factor in inducing genotoxicity. Finally, to our knowledge, this study reports for the first time increased aneuploidy after $\mathrm{Au}$ NPs exposure in vitro in a human and in a murine cell model.

\section{Acknowledgments}

This study was funded by the European Commission's Seventh Framework Programme (FP7/2007-2013) under grant agreement No CP-FP 214478-2 project name NanoReTox (http://www.nanoretox.eu) and FP7-280716 project name Sanowork (http://www.sanowork.eu).

\section{Disclosure}

The authors report no conflicts of interest in this work.

\section{References}

1. Chithrani BD, Ghazani AA, Chan WC. Determining the size and shape dependence of gold nanoparticle uptake into mammalian cells. Nano Lett. 2006;6(4):662-668.

2. Chithrani BD, Chan WC. Elucidating the mechanism of cellular uptake and removal of protein-coated gold nanoparticles of different sizes and shapes. Nano Lett. 2007;7(6):1542-1550.

3. Gao H, Shi W, Freund LB. Mechanics of receptor-mediated endocytosis. Proc Natl Acad Sci U S A. 2005;102(27):9469-9474.

4. Vetten MA, Tlotleng N, Tanner Rascher D, et al. Label-free in vitro toxicity and uptake assessment of citrate stabilised gold nanoparticles in three cell lines. Part Fibre Toxicol. 2013;10:50.

5. Greulich C, Diendorf J, Gessmann J, et al. Cell type-specific responses of peripheral blood mononuclear cells to silver nanoparticles. Acta Biomater. 2011;7(9):3505-3514.

6. Uboldi C, Bonacchi D, Lorenzi G, et al. Gold nanoparticles induce cytotoxicity in the alveolar type-II cell lines A549 and NCIH441. Part Fibre Toxicol. 2009;6:18.

7. Freese C, Uboldi C, Gibson MI, et al. Uptake and cytotoxicity of citratecoated gold nanospheres: Comparative studies on human endothelial and epithelial cells. Part Fibre Toxicol. 2012;9:23.

8. Monteiro-Riviere NA, Samberg ME, Oldenburg SJ, Riviere JE. Protein binding modulates the cellular uptake of silver nanoparticles into human cells: implications for in vitro to in vivo extrapolations? Toxicol Lett. 2013;220(3):286-293

9. Cedervall T, Lynch I, Lindman S, et al. Understanding the nanoparticleprotein corona using methods to quantify exchange rates and affinities of proteins for nanoparticles. Proc Natl Acad Sci U S A. 2007;104(7): 2050-2055.

10. Dykman L, Khlebtsov N. Gold nanoparticles in biomedical applications: recent advances and perspectives. Chem Soc Rev. 2012;41(6) 2256-2282.

11. Anderson NL, Anderson NG. The human plasma proteome: history, character, and diagnostic prospects. Mol Cell Proteomics. 2002;1(11) $845-867$. 
12. Deng ZJ, Liang M, Toth I, Monteiro M, Minchin RF. Plasma protein binding of positively and negatively charged polymer-coated gold nanoparticles elicits different biological responses. Nanotoxicology. 2013;7(3):314-322.

13. Walkey CD, Olsen JB, Guo H, Emili A, Chan WC. Nanoparticle size and surface chemistry determine serum protein adsorption and macrophage uptake. J Am Chem Soc. 2012;134(4):2139-2147.

14. Hirn S, Semmler-Behnke M, Schleh C, et al. Particle size-dependent and surface charge-dependent biodistribution of gold nanoparticles after intravenous administration. Eur J Pharm Biopharm. 2011;77(3): $407-416$.

15. Sonavane G, Tomoda K, Makino K. Biodistribution of colloidal gold nanoparticles after intravenous administration: effect of particle size. Colloids Surf B Biointerfaces. 2008;66(2):274-280.

16. Abdelhalim MA, Jarrar BM. Gold nanoparticles induced cloudy swelling to hydropic degeneration, cytoplasmic hyaline vacuolation, polymorphism, binucleation, karyopyknosis, karyolysis, karyorrhexis and necrosis in the liver. Lipids Health Dis. 2011;10:166.

17. Gosens I, Post JA, de la Fonteyne LJ, et al. Impact of agglomeration state of nano- and submicron sized gold particles on pulmonary inflammation. Part Fibre Toxicol. 2010;7(1):37.

18. Vecchio G, Galeone A, Brunetti V, et al. Concentration-dependent, size-independent toxicity of citrate capped AuNPs in Drosophila melanogaster. PLoS One. 2012;7(1):e29980.

19. Pan JF, Buffet PE, Poirier L, et al. Size dependent bioaccumulation and ecotoxicity of gold nanoparticles in an endobenthic invertebrate: the Tellinid clam Scrobicularia plana. Environ Pollut. 2012;168:37-43.

20. Coradeghini R, Gioria S, García CP, et al. Size-dependent toxicity and cell interaction mechanisms of gold nanoparticles on mouse fibroblasts. Toxicol Lett. 2013;217(3):205-216.

21. Migliore L, Frenzilli G, Nesti C, Fortaner S, Sabbioni E. Cytogenetic and oxidative damage induced in human lymphocytes by platinum, rhodium and palladium compounds. Mutagenesis. 2002;17(5):411-417.

22. Migliore L, Saracino D, Bonelli A, et al. Carbon nanotubes induce oxidative DNA damage in RAW264.7 cells. Environ Mol Mutagen. 2010;51(4):294-303.

23. Fenech, M. Cytokinesis-block micronucleus cytome assay. Nat Protoc. 2007;2(5):1084-1104.

24. Di Bucchianico S, Fabbrizi MR, Misra SK, et al. Multiple cytotoxic and genotoxic effects induced in vitro by differently shaped copper oxide nanomaterials. Mutagenesis. 2013;28(3):287-299.

25. Kroll A, Pillukat MH, Hahn D, Schnekenburger J. Interference of engineered nanoparticles with in vitro toxicity assays. Arch Toxicol. 2012;86(7):1123-1136.

26. Patra HK, Banerjee S, Chaudhuri U, Lahiri P, Dasgupta AK. Cell selective response to gold nanoparticles. Nanomedicine. 2007;3(2): 111-119.

27. Johnston HJ, Hutchison G, Christensen FM, Peters S, Hankin S, Stone V. A review of the in vivo and in vitro toxicity of silver and gold particulates: particle attributes and biological mechanisms responsible for the observed toxicity. Crit Rev Toxicol. 2010;40(4):328-346.

28. Sonavane G, Tomoda K, Makino K. Biodistribution of colloidal gold nanoparticles after intravenous administration: effect of particle size. Colloids Surf B Biointerfaces. 2008;66(2):274-280.

29. Vecchio G, Galeone A, Brunetti V, et al. Mutagenic effects of gold nanoparticles induce aberrant phenotypes in Drosophila melanogaster. Nanomedicine. 2012;8(1):1-7.

30. Smith MR, Boenzli MG, Hindagolla V, et al. Identification of gold nanoparticle-resistant mutants of Saccharomyces cerevisiae suggests a role for respiratory metabolism in mediating toxicity. Appl Environ Microbiol. 2013;79(2):728-733.

31. Elbakry A, Wurster EC, Zaky A, et al. Layer-by-layer coated gold nanoparticles: size-dependent delivery of DNA into cells. Small. 2012;8(24):3847-3856.

32. Oh E, Delehanty JB, Sapsford KE, et al. Cellular uptake and fate of PEGylated gold nanoparticles is dependent on both cell-penetration peptides and particle size. ACS Nano. 2011;5(8):6434-6448.
33. Li JJ, Zou L, Hartono D, Ong CN, Bay BH, Lanry Yung LY. Gold Nanoparticles Induce Oxidative Damage in Lung Fibroblasts In Vitro. Adv Mater. 2008;20(1):138-142.

34. Sumbayev VV, Yasinska IM, Garcia CP, et al. Gold nanoparticles downregulate interleukin-1 $\beta$-induced pro-inflammatory responses. Small. 2013;9(3):472-477.

35. Mayer A, Vadon M, Rinner B, Novak A, Wintersteiger R, Fröhlich E. The role of nanoparticle size in hemocompatibility. Toxicology. 2009;258(2-3):139-147.

36. Love SA, Thompson JW, Haynes CL. Development of screening assays for nanoparticle toxicity assessment in human blood: preliminary studies with charged $\mathrm{Au}$ nanoparticles. Nanomedicine (Lond). 2012;7(9):1355-1364.

37. Zhang XD, Wu D, Shen X, et al. Size-dependent in vivo toxicity of PEG-coated gold nanoparticles. Int J Nanomedicine. 2011;6: 2071-2081.

38. Nel A, Xia T, Mädler L, Li N. Toxic potential of materials at the nanolevel. Science. 2006;311(5761):622-627.

39. Papageorgiou I, Brown C, Schins R, et al. The effect of nano- and micron-sized particles of cobalt-chromium alloy on human fibroblasts in vitro. Biomaterials. 2007;28(19):2946-2958.

40. Schaeublin NM, Braydich-Stolle LK, Schrand AM, et al. Surface charge of gold nanoparticles mediates mechanism of toxicity. Nanoscale. 2011;3(2):410-420.

41. Thomas P, Umegaki K, Fenech M. Nucleoplasmic bridges are a sensitive measure of chromosome rearrangement in the cytokinesisblock micronucleus assay. Mutagenesis. 2003;18(2):187-194.

42. Schulz M, Ma-Hock L, Brill S, et al. Investigation on the genotoxicity of different sizes of gold nanoparticles administered to the lungs of rats. Mutat Res. 2012;745(1-2):51-57.

43. Downs TR, Crosby ME, Hu T, et al. Silica nanoparticles administered at the maximum tolerated dose induce genotoxic effects through an inflammatory reaction while gold nanoparticles do not. Mutat Res. 2012;745(1-2):38-50.

44. Paino IM, Marangoni VS, de Oliveira Rde C, Antunes LM, Zucolotto V. Cyto and genotoxicity of gold nanoparticles in human hepatocellular carcinoma and peripheral blood mononuclear cells. Toxicol Lett. 2012;215(2):119-125.

45. Geffroy B, Ladhar C, Cambier S, Treguer-Delapierre M, Brèthes D, Bourdineaud JP. Impact of dietary gold nanoparticles in zebrafish at very low contamination pressure: the role of size, concentration and exposure time. Nanotoxicology. 2012;6(2):144-160.

46. Choi SY, Jeong $\mathrm{S}$, Jang $\mathrm{SH}$, et al. In vitro toxicity of serum proteinadsorbed citrate-reduced gold nanoparticles in human lung adenocarcinoma cells. Toxicol In Vitro. 2012;26(2):229-237.

47. Di Guglielmo C, De Lapuente J, Porredon C, Ramos-López D, Sendra J, Borràs $M$. In vitro safety toxicology data for evaluation of gold nanoparticles-chronic cytotoxicity, genotoxicity and uptake. J Nanosci Nanotechnol. 2012;12(8):6185-6191.

48. Li JJ, Lo SL, Ng CT, et al. Genomic instability of gold nanoparticle treated human lung fibroblast cells. Biomaterials. 2011;32(23): 5515-5523.

49. Herrera LA, Prada D, Andonegui MA, Dueñas-González A. The epigenetic origin of aneuploidy. Curr Genomics. 2008;9(1):43-50.

50. Inglot $\mathrm{P}$, Lewinska A, Potocki L, et al. Cadmium-induced changes in genomic DNA-methylation status increase aneuploidy events in a pig Robertsonian translocation model. Mutat Res. 2012;747(2): $182-189$

51. Yang Y, Qu Y, Lü X. Global gene expression analysis of the effects of gold nanoparticles on human dermal fibroblasts. J Biomed Nanotechnol. 2010;6(3):234-246

52. Ng CT, Dheen ST, Yip WC, Ong CN, Bay BH, Lanry Yung LY. The induction of epigenetic regulation of PROS1 gene in lung fibroblasts by gold nanoparticles and implications for potential lung injury. Biomaterials. 2011;32(30):7609-7615.

53. Stoccoro A, Karlsson HL, Coppedè F, Migliore L. Epigenetic effects of nano-sized materials. Toxicology. 2013;313(1):3-14. 


\section{Supplementary materials}

A

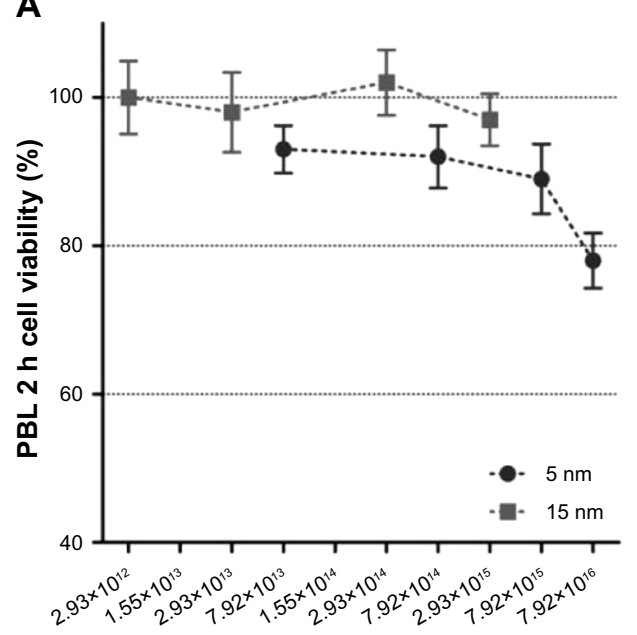

Number of Au NPs

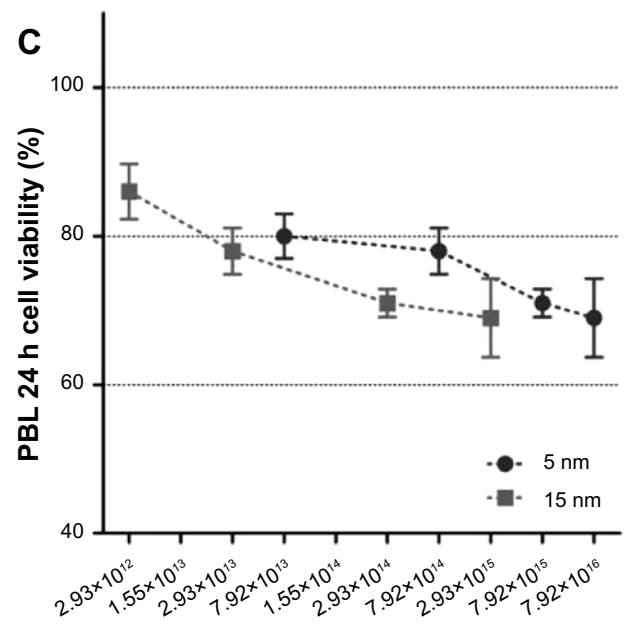

Number of Au NPs
B

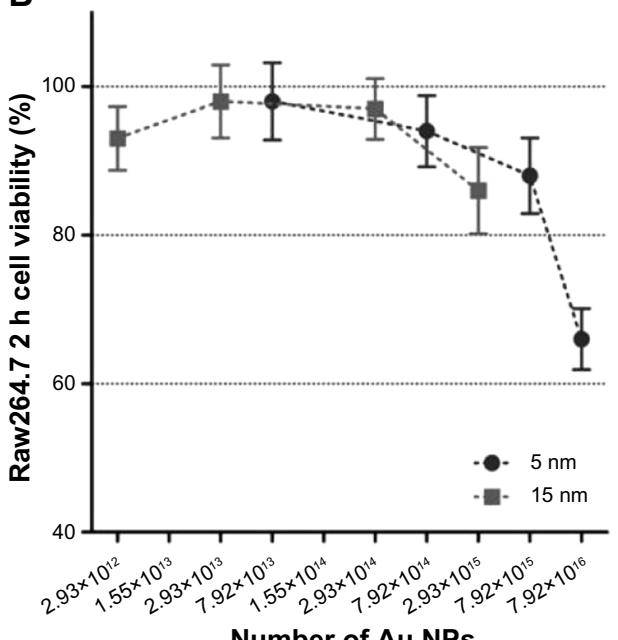

Number of Au NPs

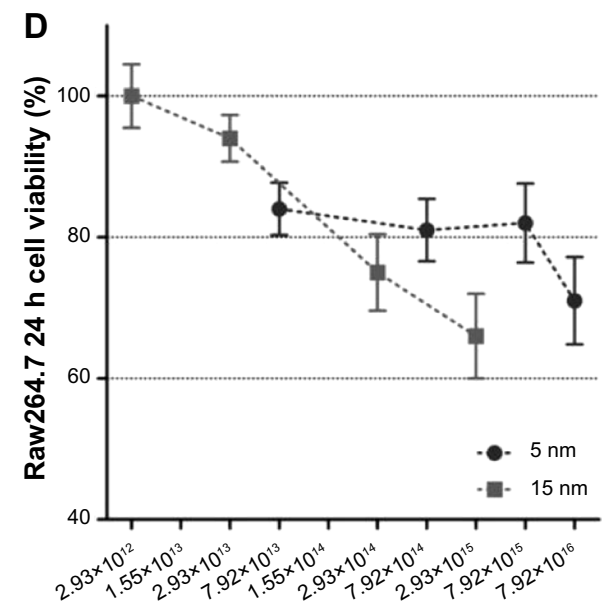

Number of Au NPs

Figure SI Cell viability evaluated by MTT assay in function of the theoretically calculated number of $5 \mathrm{~nm}$ and $15 \mathrm{~nm}$ Au NPs.

Notes: Mass concentrations $(0.1-100 \mu \mathrm{g} / \mathrm{mL})$ were expressed as theoretically calculated number of Au NPs ranging from $2.93 \times 10^{12}$ to $7.92 \times 10^{16}$. In PBL $(\mathbf{A}$ and $\mathbf{C})$ and Raw264.7 (B and D), after 2 hours (A and B) and 24 hours (C and D) treatment, no statistically significant differences among the cytotoxicity of $5 \mathrm{~nm}$ and $15 \mathrm{~nm}$ Au NPs were observed. Data show the percent of viable cells normalized to untreated control $( \pm$ SEM, $n=9)$. Statistical analysis was performed by Student's $t$-test.

Abbreviations: Au NP, gold nanoparticles; MTT, methylthiazol tetrazolium; PBL, peripheral blood lymphocytes; SEM, standard error of the mean. 
A

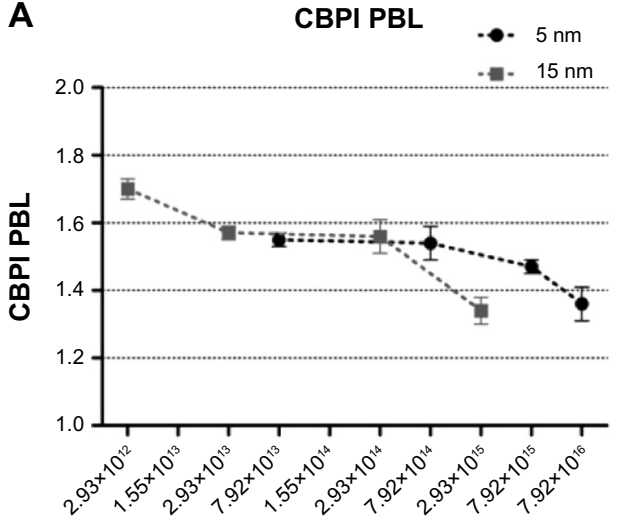

Number of Au NPs

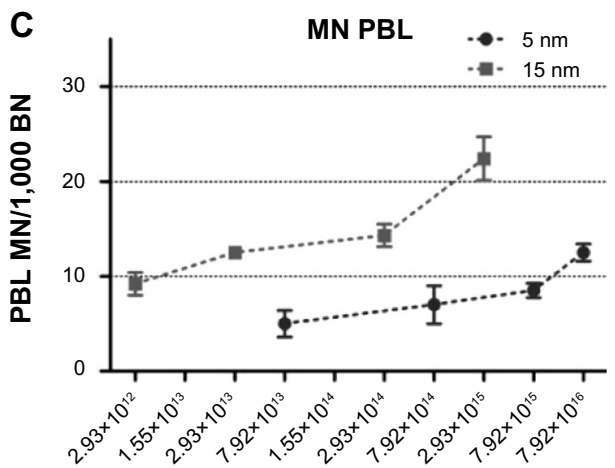

Number of Au NPs

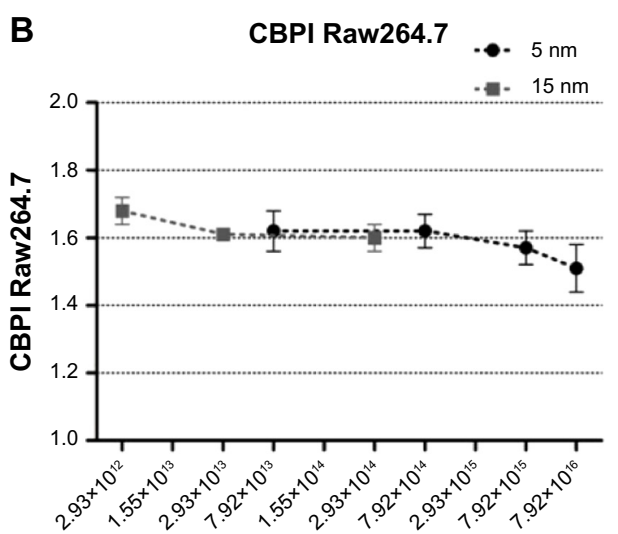

Number of Au NPs

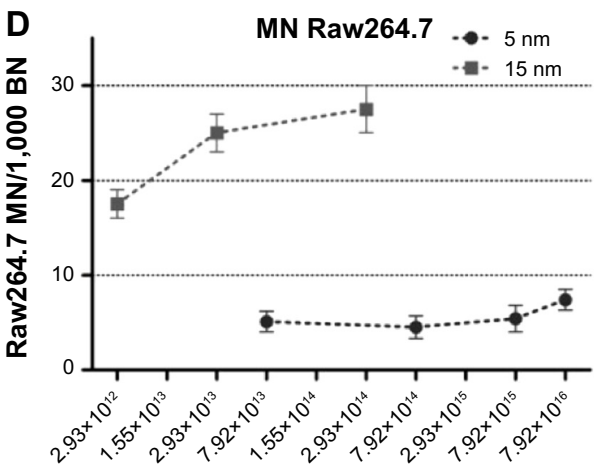

Number of Au NPs

Figure S2 CBPI and MN frequency evaluated by CBMN Cyt assay in function of the theoretically calculated number of $5 \mathrm{~nm}$ and I5 nm Au NPs.

Notes: While CBPI shows no differences in antiproliferative activity of $5 \mathrm{~nm}$ and 15 Au NPs in PBL (A) and Raw264.7 (B), MN frequency was higher in PBL (C) and Raw264.7 (D) exposed to $15 \mathrm{~nm}$ Au NPs than to $5 \mathrm{~nm}(P<0.05)$. Data are shown as mean \pm SEM (PBL: $n=4$; Raw264.7: $n=6)$. Statistical analysis was performed by Student's $t$-test. Abbreviations: Au NP, gold nanoparticle; BN, binucleated cells; CBMN Cyt, cytokinesis-block micronucleus cytome; CBPI, cytokinesis block proliferation index; MN, micronuclei; PBL, peripheral blood lymphocytes; SEM, standard error of the mean.

\section{Publish your work in this journal}

The International Journal of Nanomedicine is an international, peerreviewed journal focusing on the application of nanotechnology in diagnostics, therapeutics, and drug delivery systems throughout the biomedical field. This journal is indexed on PubMed Central, MedLine, CAS, SciSearch $\AA$, Current Contents ${ }^{\circledR} /$ Clinical Medicine,
Journal Citation Reports/Science Edition, EMBase, Scopus and the Elsevier Bibliographic databases. The manuscript management system is completely online and includes a very quick and fair peer-review system, which is all easy to use. Visit http://www.dovepress.com/ testimonials.php to read real quotes from published authors. 